\title{
Associations between Melatonin, Neuroinflammation, and Brain Alterations in Depression
}

\author{
Eunsoo Won ${ }^{1,2}$, Kyoung-Sae $\mathrm{Na}^{3}(\mathbb{D})$ and Yong-Ku Kim ${ }^{4, *(D)}$ \\ 1 Department of Psychiatry, Chaum, Seoul 06062, Korea; eunsooowon@gmail.com \\ 2 Department of Psychiatry, CHA Bundang Medical Center, CHA University, Seongnam 13496, Korea \\ 3 Department of Psychiatry, Gachon University Gil Medical Center, Incheon 21565, Korea; ksna13@gmail.com \\ 4 Department of Psychiatry, Korea University Ansan Hospital, Korea University College of Medicine, \\ Ansan 15355, Korea \\ * Correspondence: yongku@korea.ac.kr
}

Citation: Won, E.; Na, K.-S.;

Kim, Y.-K. Associations between

Melatonin, Neuroinflammation, and

Brain Alterations in Depression. Int

J. Mol. Sci. 2022, 23, 305. https://

doi.org/10.3390/ijms23010305

Academic Editor: Zoya Marinova

Received: 2 November 2021

Accepted: 26 December 2021

Published: 28 December 2021

Publisher's Note: MDPI stays neutral with regard to jurisdictional claims in published maps and institutional affiliations.

Copyright: (C) 2021 by the authors. Licensee MDPI, Basel, Switzerland. This article is an open access article distributed under the terms and conditions of the Creative Commons Attribution (CC BY) license (https:// creativecommons.org/licenses/by/ $4.0 /)$.

\begin{abstract}
Pro-inflammatory systemic conditions that can cause neuroinflammation and subsequent alterations in brain regions involved in emotional regulation have been suggested as an underlying mechanism for the pathophysiology of major depressive disorder (MDD). A prominent feature of MDD is disruption of circadian rhythms, of which melatonin is considered a key moderator, and alterations in the melatonin system have been implicated in MDD. Melatonin is involved in immune system regulation and has been shown to possess anti-inflammatory properties in inflammatory conditions, through both immunological and non-immunological actions. Melatonin has been suggested as a highly cytoprotective and neuroprotective substance and shown to stimulate all stages of neuroplasticity in animal models. The ability of melatonin to suppress inflammatory responses through immunological and non-immunological actions, thus influencing neuroinflammation and neurotoxicity, along with subsequent alterations in brain regions that are implicated in depression, can be demonstrated by the antidepressant-like effects of melatonin. Further studies that investigate the associations between melatonin, immune markers, and alterations in the brain structure and function in patients with depression could identify potential MDD biomarkers.
\end{abstract}

Keywords: melatonin; neuroinflammation; major depressive disorder; biomarker

\section{Introduction}

Recently, changes in the immune system that lead to neuroinflammation and subsequent alterations in brain regions involved in emotional regulation have been suggested to have a central role in the pathophysiology of major depressive disorder (MDD) [1] In previous studies, immune system dysfunction has been reported, demonstrated by pro-inflammatory conditions in patients with MDD [2-5]. The association between increased inflammatory markers and depression can be explained by the neurotoxic effects of neuroinflammation on specific brain regions involved in emotion regulation [6]. In addition, previous imaging studies of patients with depression have reported changes in the structure or function of brain areas in pro-inflammatory states [7].

A prominent feature of MDD is a disruption of sleep-wake cycles. In addition, research has identified a complex bidirectional link between sleep and depression, and a common finding in depressed patients is a habit of sleeping at a time that is out of phase with the body's biological rhythms [8]. Extensive literature has shown that sleep disruption is an underlying component of the pathophysiology of depression [9], with a majority of patients complaining of insomnia or hypersomnia [10,11]. Sleep has been divided into rapid eye movement (REM) and non-rapid eye movement (NREM) sleep based on polysomnography signals, with a minimum of $20 \%$ high-voltage, low-frequency cortical $\delta$ waves present in NREM sleep. Therefore, NREM sleep is also referred to as slow-wave sleep [12]. Studies that have used sleep electroencephalograms have shown characteristic changes in NREM and 
REM sleep in depression, such as sleep continuity disruption, decreases in non-rapid eye movement sleep production and rapid eye movement (REM) sleep latency, and increases in REM sleep duration and frequency $[11,13]$.

The central pacemaker of the circadian rhythm is the suprachiasmatic nucleus (SCN) of the hypothalamus [14], which synchronizes physiological and behavioral rhythms with $24 \mathrm{~h}$ periodicity of the light-dark cycle, with light being the primary stimulus for orienting the SCN-induced rhythms with the external environment [12]. The relationship between depressive-like behavior and disruption of biological rhythms has been widely reported in both animal and human studies [15]. Rodents exposed to short photoperiods showed depression-like behavior [16] and lower dopaminergic and somatostatin neuron levels in the hypothalamus [17]. Disruption of central SCN rhythms was associated with helplessness, despair, and anxiety-like behaviors [18]. In clinical studies, moderate changes in the timing of the sleep-wake cycle were shown to have profound effects on subsequent mood [19] and the rhythmicity of specific mood-related symptoms and behaviors was associated with a risk for psychiatric disorders [20].

The SCN generates a neural output signal that induces melatonin synthesis from the pineal gland in dimmed light, and melatonin is considered one of the most important moderators of circadian rhythm [21]. The sleep-wake cycle is the most overt circadian rhythm and is highly affected by melatonin as a physiological sleep regulator [12]. Concerning the pathophysiology of depression, dysfunction in monoamine neurotransmission has been most widely studied, with current antidepressant treatment concentrated on normalization of monoamines, such as serotonin, norepinephrine, and dopamine [22]. Because serotonin is the precursor of melatonin, and norepinephrine and dopamine influence melatonin production [23], given the central role of melatonin in sleep, several clinical studies have investigated the association between melatonin level and depression. However, results have been inconsistent and reported lower serum or saliva levels of melatonin, no difference in levels, or even higher levels in depressed individuals compared to controls [24-29]. Although the association between melatonin and depression has been explained more widely by regulatory effects of melatonin on sleep and the circadian rhythm, the inconsistencies of previous studies suggest that melatonin could potentially influence mood through diverse physiological actions, in addition to regulating the circadian rhythm.

Melatonin has been reported to influence various immunomodulatory actions in both in vivo and in vitro models [30]. Melatonin has also been shown to have cytoprotective properties [31] that are related to its immunoregulatory effects and its antioxidant and scavenging capacities [32]. Melatonin can inhibit pro-oxidant enzyme synthesis, facilitate antioxidant enzyme synthesis, and protect from oxidative damage [33]. Melatonin has also been suggested to exert cytoprotection through membrane stabilization [34]. The $\gamma$-aminobutyric acid (GABA)-ergic system might be associated with melatonin's neuroprotective actions, as one study has suggested that melatonin extends protection to neurons by activating GABAergic receptors [35]. Melatonin's anti-excitotoxic activity has also been reported in previous studies [36]. Melatonin has been reported to reduce neuronal damage in animal models of Alzheimer's disease (AD) [37] and Parkinson's disease (PD) [38], along with brain trauma [39,40], focal ischemia [41], cadmium [42,43], $\delta$-aminolevulinic acid [44] toxicity, hyperbaric hyperoxia [45,46], $\gamma$ radiation [47], and several neurotoxins [48].

In this review, we evaluated the influence of melatonin on the immune system and neuroinflammation, along with the cytoprotective properties, which might influence brain structure and function, contributing to the pathophysiology of MDD.

\section{The Immune System and Neuroinflammation in Depression}

The hypothalamus secretes corticotropin-releasing hormone in response to stress, and these neurons project from the paraventricular nucleus of the hypothalamus to the noradrenergic centers of the brainstem and spinal cord [49]. The locus coeruleus of the brainstem sends direct projections to the sympathetic and parasympathetic preganglionic neurons in the spinal cord [49], increases sympathetic activity, and decreases parasym- 
pathetic activity through $\alpha 1$ - and $\alpha 2$-adrenoceptors, respectively [50,51]. The principal neurotransmitters of the autonomic nervous system (ANS) are norepinephrine (NE) and acetylcholine (ACh) [52], and the sympathetic nervous system (SNS) primarily acts by releasing NE, whereas the parasympathetic nervous system (PNS) mainly uses ACh as its neurotransmitter [53,54]. The SNS controls epinephrine (E) and NE biosynthesis and secretion from the adrenal medulla [55]. In response to stress, the SNS is activated and stimulates medullary cells to release E and NE into the blood [56]. When the stressor is terminated, the PNS is activated and $\mathrm{ACh}$ is released to stimulate the muscarinic receptors of the target organs [57]. However, when a stressful situation persists, as in MDD, the SNS continues to be activated without normal counteraction of the PNS and the catecholamine level can increase while the acetylcholine level decreases [58]. Catecholamines modulate cytokine release through $\alpha$ - and $\beta$-adrenoceptors on immune cells [59]. NE has been shown to enhance the production of TNF- $\alpha[60,61]$, and $\mathrm{E}$ and NE have both been shown to stimulate the production of IL-6 [62]. NE has also been shown to augment macrophage phagocytosis and tumoricidal activity [63]. In comparison, ACh has been shown to inhibit the production of TNF- $\alpha$ along with other pro-inflammatory cytokines, such as IL-1 $\beta$, IL- 6 , and IL-18 [64], and is considered to be immunoinhibitory [65]. Therefore, in chronically stressful situations, such as MDD, continuous sympathetic activity together with insufficient parasympathetic activity can increase catecholamine levels and decrease acetylcholine levels to increase pro-inflammatory cytokine levels. Accordingly, depression-like symptoms can be induced by pro-inflammatory cytokines and reversed by pro-inflammatory cytokine receptor antagonists [66]. The association between immune activation and depression has been repeatedly suggested [67-69], along with improvement in depressive symptoms with pro-inflammatory cytokine antagonist treatment [70]. Studies on medically healthy subjects have reported an association between depressed mood and increased pro-inflammatory cytokine production, and studies on patients with MDD have reported increased levels of pro-inflammatory cytokines, such as IL-1 $\beta$, IL-6, and TNF- $\alpha$ [2-4]. Furthermore, c-reactive proteins (CRPs) are increased following IL-6 secretion [5] and have been reported to be elevated in patients with MDD [71-73]. The link between increased inflammatory markers and depression can be explained by the toxic effects of neuroinflammation on specific brain regions involved in depression.

Increases in pro-inflammatory cytokines can influence the brain by increasing neurotoxic metabolites through the kynurenine pathway or by directly exerting neurotoxic effects on specific brain regions [7]. Pro-inflammatory cytokines activate the kynurenine pathway, resulting in an increase in neurotoxic kynurenine pathway metabolites, including 3-hydroxykynurenine, 3-hydroxyanthranilic acid, and quinolinic acid [74], and decreases in the neuroprotective kynurenine pathway metabolite kynurenic acid [75]. The potent free radical donor, 3-hydroxykynurenine, promotes oxidative stress, which can lead to neuronal apoptosis [76,77]. In addition, 3-hydroxyanthranilic acid produces reactive hydrogen peroxide and hydroxyl radicals by auto-oxidation [78]. Quinolinic acid triggers NMDA receptors, stimulates glutamate release, inhibits glutamate reuptake, and reduces glutamine synthetase action, which lead to increased extracellular glutamate and excitatory neuron activation, which cause excitotoxicity and apoptosis $[79,80]$. Quinolinic acid also induces mitochondrial dysfunction, cytochrome $\mathrm{c}$ release, ATP exhaustion, free radical formation, and oxidative damage [81]. Furthermore, brain areas important for emotional regulation can be directly influenced by excess activation of brain cytokine networks; further, pro-inflammatory cytokines can decrease neurotrophic support and neurogenesis through brain-derived neurotrophic factor signaling pathway downregulation [82-84], reduce cell proliferation through the nuclear factor-kappa B signaling pathway [85], and increase the glutamate level to result in excitotoxicity and reduced neurogenesis through NMDA receptor activation $[86,87]$.

A previous study investigated the association between serum concentrations of kynurenine pathway metabolites and hippocampal and amygdala volumes in patients with MDD; the kynurenic acid/quinolinic acid ratio was positively correlated with hippocampal and 
amygdala volumes [88]. Another study evaluated the impact of changes in the glucocorticoid and inflammatory systems and how they affect hippocampal volumes in MDD, reporting a negative effect of IL-6 concentration on the hippocampal volume [89]. Another study investigated neuroinflammation in individuals with late-life depression and reported elevated CRP levels and hippocampal structural reductions [90]. In a study that investigated whether increased inflammation in major depression affects corticostriatal reward circuitry, increased CRP levels were associated with decreased connectivity between the ventral striatum and ventromedial prefrontal cortex (vmPFC) and striatum and vmPFC connectivity was associated with increased plasma IL-6, IL-1 $\beta$, and IL-1 receptor antagonists [91].

Therefore, conditions that influence systemic inflammation and subsequent neuroinflammation and those that can induce alterations in brain regions related to emotional regulation might contribute to the pathophysiology of MDD. As melatonin has immunomodulatory and cytoprotective actions, disruption of the melatonin system has been implicated in MDD.

\section{Melatonin Synthesis and Secretion}

Melatonin is a neurohormone primarily produced by the pineal gland [92] and also by other organs, including the cerebellum, skin [93], retina, Harderian gland [94], lymphocytes [95], platelets [96], bone marrow cells [97], and the gastrointestinal (GI) tract [98]. Particularly in the GI tract, enterochromaffin cells synthesize and secrete melatonin into circulation based on food (tryptophan) intake and melatonin concentrations in the GI tract are several hundred times higher than that in the blood or the pineal gland [98,99]. GI melatonin can be released into circulation, especially under conditions of high dietary tryptophan levels $[31,98]$. The melatonin level remains relatively stable until $35-40$ years of age and then gradually decreases, with minimal difference in day and night levels at $\geq 65$ years of age [100-102].

The first step in melatonin formation is the uptake of L-tryptophan from circulation into the pineal gland [100]. L-tryptophan is hydroxylated by tryptophan-5-hydroxylase into 5-hydroxytryptophan and then decarboxylated by 5-hydroxytryptophan decarboxylase into serotonin. Serotonin is acetylated by arylalkylamine- $N$-acetyltransferase into $\mathrm{N}$-acetylserotonin and then methylated by acetylserotonin-O-methyltransferase into melatonin; arylalkylamine- $N$-acetyltransferase is the rate-limiting enzyme for this process $[99,103,104]$. Once synthesized, melatonin is released into the bloodstream instead of being stored in pineal cells [105]. Because norepinephrine increases adenylate cyclase activity, noradrenergic projections to the pineal gland control arylalkylamine- $\mathrm{N}$ acetyltransferase activity, which subsequently enhances arylalkylamine- $N$-acetyltransferase activity [23]. Circulating melatonin is metabolized primarily in the liver and secondarily in the kidney. Melatonin is hydroxylated to 6-hydroxymelatonin, followed by sulfate conjugation to 6-hydroxymelatonin sulfate $(90 \%)$ or glucuronide conjugation to 6hydroxymelatonin glucuronide $(10 \%)$, with approximately $5 \%$ of serum melatonin being excreted unmetabolized through urine. Minor metabolites of melatonin include cyclic 2hydroxymelatonin, $\mathrm{N}$-gamma-acetyl- $\mathrm{N}$-2-formyl-5-methoxykynurenamine, and $\mathrm{N}$-gammaacetyl-5-methoxykynurenamine [31,100].

The synthesis and secretion of melatonin are influenced by light, with darkness increasing and light inhibiting both processes. Melatonin is the main circadian output marker of the brain, along with cortisol, and its synthesis and secretion are regulated by light through retinal ganglion cells and melanopsin. Photosensory information arrives at the pineal gland through a polyneuronal pathway that includes the retinohypothalamic tract, which projects from the retina to the SCN, the major circadian oscillator $[31,92,100,106]$. Fibers from the SCN influence the intermediolateral horn cells of the spinal cord, where preganglionic sympathetic neurons that innervate the superior cervical ganglion are located. Subsequently, the postganglionic sympathetic fibers terminate on the pinealocytes and regulate melatonin synthesis by releasing norepinephrine [31,106]. 
Melatonin is released predominantly at night because light suppresses the activity of enzymes that synthesize it [107]. Light passes through the retina, and information is transferred to the SCN of the hypothalamus and eventually to the pineal gland [108]. Rhythmic synthesis and secretion of melatonin are generated by the circadian pacemaker situated in the SCN and synchronized based on the $24 \mathrm{~h}$ light-dark cycle [100]. Melatonin secretion begins with the dimming of light (sundown), with the onset usually around 9-10 pm., gradually increases and reaches its peak around 2-3 am., and gradually decreases until sunrise [109]. During the night, approximately $80 \%$ of the melatonin is synthesized and maintained in the serum at a concentration of $80-120 \mathrm{pg} / \mathrm{mL}$, compared with a daytime serum concentration of 10-20 pg/mL [99,100]. The half-life of serum melatonin is less than $60 \mathrm{~min}[31,101,110]$. Endogenous oscillators within the SCN control the circadian production of pineal melatonin based on the environmental light-dark cycle [111].

Pineal melatonin is released into the third ventricle and then into general circulation [92]. Melatonin has several targets, mainly G-protein-coupled receptors that are classified into three groups: MT1 (Mel1a), MT2 (Mel1b), and GPR50 (mammals)/Mel1c (non-mammals) [112-115]. Melatonin has high affinity for MT1 and MT2 but not for GPR50 in mammals; as an agonist of these receptors, it leads to G protein activation and beta-arrestin recruitment $[112,116,117]$. In humans, MT1 is located on chromosome 4q35.1 and MT2 is located on chromosome 11q21-22, with 60\% homology to MT1 $[100,113,118]$. MT1 inhibits adenylate cyclase and stimulates inositol phosphate, and MT2 inhibits cyclic adenosine monophosphate (cAMP) and cyclic guanosine monophosphate (cGMP) formation $[100,119,120]$. The vitamin D receptor, a nuclear receptor, has been reported to bind melatonin directly [121], as have enzymes such as quinone reductase 2, metalloprotease-9, pepsin, and protein phosphatase 2 [122-125]. In mammals, high-affinity melatonin receptors are primarily located in the hypothalamus and pars tuberalis of the anterior lobe of the pituitary gland in the brain [100]. MT1 is distributed in the retina, the cornea, the anterior pituitary, the SCN, the cortex, the amygdala, the hippocampus, the thalamus, substantia nigra, nucleus accumbens, and the cerebellum $[99,126]$. MT2 is distributed in the retina, the cortex, the hippocampus, the paraventricular nucleus, and the cerebellum [99,127]. Melatonin receptors are also present in peripheral tissues, including the heart, lungs, the liver, the gallbladder, the adrenal gland, the small intestine, kidneys, the prostate, breasts, ovaries, the uterus, adipocytes, the skin, T lymphocytes, and B lymphocytes [99,107].

\section{Biological Effects of Melatonin}

Melatonin functions as an endogenous synchronizer, and melatonin synthesis is rapidly suppressed even in the dark phase by acute light exposure of sufficient intensity $[100,128]$. In numerous studies, melatonin has been shown to synchronize circadian rhythms when binding to MT-receptors in the SCN [107]. Melatonin delayed circadian rhythms when it was administered in the morning and advanced circadian rhythms when administered in the afternoon or early evening [129]. Melatonin was also shown to readjust after acute light-dark phase shifts, such as jet lag and shift work [130]. Furthermore, administration of melatonin was shown to entrain circadian rhythms in most blind individuals that had free-running rhythms [131]. Inhibition of dopamine release by melatonin has been demonstrated in specific areas of the mammalian central nervous system, including the hypothalamus, the hippocampus, the medulla-pons, and the retina, and the interaction of melatonin with the dopaminergic system has been hypothesized to have a significant role in nonphotic and photic entrainment of the biological clock [132].

Melatonin secretion has also been suggested to be important in regulating memory processes [133]. The presence of melatonin receptors in the human hippocampus has been widely acknowledged [134], with MT1 predominantly present in the cornus ammonis (CA)1 subfield [135] and MT2 in the CA4 and CA3 subfields [136]. Melatonin has been shown to have both enhancing and inhibitory effects on the excitability of hippocampal neurons $[133,136,137]$, along with vasoactive effects in the hippocampus [138]. Other biological effects of melatonin include antiepileptic effects [139-143] via antioxidant activities [144], 
increase in $\gamma$-aminobutyric acid (GABA) concentration [145] and GABA receptor affinity [146], and decreases in N-methyl-D-aspartate (NMDA) excitatory levels [147]. However, proconvulsant effects of melatonin have also been reported [148].

\section{Melatonin and Inflammation}

A bidirectional communication system has been identified, with melatonin acting on the immune system, and vice versa [149]. As the pineal gland is an immune target, cytokines such as interferon-gamma (IFN- $\gamma$ ) [150] and tumor necrosis factor-alpha (TNF- $\alpha$ ) [151] have been shown to influence the melatonin level. Numerous studies have suggested endogenous synthesis of melatonin by the immune system [152], considered a source of extra-pineal melatonin $[153,154]$. Furthermore, melatonin receptors have been shown to be present in the immune cells of various species $[155,156]$. In comparison, melatonin has been shown to modulate immune responses $[157,158]$. In both normal and immunosuppressed conditions, melatonin has been shown to exert immune-enhancing effects, such as increasing the number of immune-related cells (including macrophages [159]; NK cells [160]; interleukin (IL)-1 $\beta$ [161], IL-6, and IL-12 [162]; splenic CD4(+) cells [163]; IgG1 and IgM [164]; and IL-2 and IFN- $\gamma$ [165]). However, in conditions with exacerbated immune responses, melatonin decreased immune reactions, represented by a reduction in neutrophil infiltration [166], migration of neutrophils and monocytes [167], and levels of cyclooxygenase-2 (COX-2) and nitric oxide synthase (iNOS) [168]. Additionally, numerous animal and clinical studies have indicated that melatonin mitigates pro-inflammatory cytokine production [169-174].

Immunomodulatory actions of melatonin have been widely reported [30], and melatonin has been found to have either pro- or anti-inflammatory effects [149,175], depending on the systemic condition. In normal conditions and immunosuppressed conditions, melatonin was shown to exert immune-enhancing effects. A study that examined the response of macrophages/microglia to multiple injections of melatonin in the pineal gland and different regions of the brain reported a significant increase in macrophage/microglia cellularity [159]. Further, melatonin injection was shown to induce natural killer (NK) cell activity [160] and humans treated with melatonin showed an increased neutrophil chemotactic response, with melatonin suggested as having a relevant role during the tissue leukocyte infiltration in inflammatory and immune responses [176]. Melatonin administration to normal and immune-depressed mice significantly increased antibody responses and restored impaired T-helper cell activity [177]. Melatonin was also suggested to exert an additive effect on the modulation of phagocytic function [178]. Melatonin stimulated the production of IL-2 and IL-1 $\beta$, which stimulated cell immunity [161], and melatonin administration after trauma-hemorrhage was shown to significantly improve depressed immune functions, which was confirmed by the restoration of peritoneal macrophage IL-1 and IL-6 release, as well as significantly improve splenocyte IL-2 and IL-3 release and splenocyte proliferative capacity [179]. Melatonin activated human Th1 lymphocytes by increasing the production of IL-2 and IFN- $\gamma$ in vitro [162].

In comparison, in exacerbated immune response states, melatonin has predominantly shown immune-dampening effects, with various studies reporting a reduction in proinflammatory cytokine levels in models of high- or medium-grade inflammation [180-184]. Melatonin attenuated TNF- $\alpha$, IL-1 $\beta$, and IL-6; promoted plasma levels of anti-inflammatory cytokine IL-10; and reduced polymorphonuclear neutrophil infiltration in heatstroke rats [166]. The beneficial effect of melatonin on acute pancreatitis was related to a decline in pro-inflammatory cytokines such as TNF- $\alpha$ and stimulation of anti-inflammatory IL-10, along with a decrease in neutrophil infiltration [185]. In rats with transient focal cerebral ischemia, intravenous administration of melatonin decreased the emigration of circulatory neutrophils and macrophages/monocytes into the injured brain and inhibited focal microglial activation [167]. Another study suggested that the reduction in vascular permeability induced by local melatonin injection mediated a reduction in the ability of endothelial cells to interact with neutrophils [186]. Melatonin has also been shown to inhibit 
lipopolysaccharide (LPS)-induced cyclooxygenase-2 (COX2) and inducible nitric oxide synthase (INOS) protein levels [168] and was suggested to have anti-inflammatory functions through down-regulation of chemokine expression by inhibiting nuclear factor kappa-lightchain-enhancer of activated B cells (NF- $\mathrm{KB}$ ) in an LPS-stimulated BV2 murine microglial cell line [187]. Melatonin also suppressed IL-8 production in human pulmonary fibroblasts [188] and inhibited LPS-mediated production of TNF- $\alpha$ and IL-8 in neutrophils [189]. Additionally, numerous animal and clinical studies have shown that melatonin mitigates pro-inflammatory cytokine production in inflammatory states, including TNF- $\alpha$, IFN- $\gamma$, IL-1 $\beta$, IL-2, IL-6, IL-8, and IL-12 [166,169-174,190-210] (Table 1). However, in some studies, melatonin did not prevent increases in pro-inflammatory cytokines in models of high-grade inflammation [211,212].

Table 1. Melatonin and pro-inflammatory cytokine production in an inflammatory state.

\begin{tabular}{|c|c|c|c|}
\hline Inflammatory State & Effect of Melatonin Administration & Species & Reference \\
\hline $\begin{array}{l}\text { Heatstroke-associated multiple organ dysfunction syndrome } \\
\text { resembling septic shock }\end{array}$ & Attenuates TNF- $\alpha$, IL-1 $\beta$, and IL-6 & Rodent & [166] \\
\hline $\begin{array}{l}\text { Overexpression of inflammatory mediators induced in the } \\
\text { heart by acute exercise }\end{array}$ & Prevents increase in TNF- $\alpha$, IL-1, and IL-6 mRNA & Rodent & [169] \\
\hline Cerulein-induced acute pancreatitis & Reduces the expression of TNF- $\alpha$, IL- $1 \beta$, IL- 6 , and IL- 8 & Rodent & [170] \\
\hline $\begin{array}{l}\text { Aerosolized pancreatic fluid introduced into airways to } \\
\text { induce inflammation }\end{array}$ & Reduces mRNA and protein expression of TNF- $\alpha$ & Rodent & [171] \\
\hline Intracerebroventricular administration of LPS & Attenuates TNF- $\alpha$ and IL-1 $\beta$ & Rodent & [172] \\
\hline Duchenne muscular dystrophy & Attenuates IL-1 $\beta$ IL-2, IL-6, TNF- $\alpha$, and IFN- $\gamma$ & Human & [173] \\
\hline LPS administration to pregnant mice & $\begin{array}{l}\text { Attenuates the LPS-evoked elevation of TNF- } \alpha \text { in } \\
\text { maternal serum and fetal brain }\end{array}$ & Rodent & [174] \\
\hline Respiratory distress syndrome & Attenuates TNF- $\alpha$, IL- 6 , and IL- 8 & Human & [190] \\
\hline Endotracheal intubation & Attenuates IL-6, IL-8, and IL-12 & Human & [191] \\
\hline Alzheimer's transgenic mice & Attenuates TNF- $\alpha$ in the hippocampus & Rodent & [192] \\
\hline Generation of chronic gastric ulcers by indomethacin & $\begin{array}{l}\text { Blocks increase in the expression of TNF- } \alpha \text {, IL- } 1 \beta \text {, } \\
\text { and IL- } 8\end{array}$ & Rodent & [193] \\
\hline Radiation-induced lung injury & Reduces the elevation of TNF- $\alpha$ expression & Rodent & [194] \\
\hline Bacillus Calmette-Guérin/LPS-induced hepatic injury & Attenuates increase in TNF- $\alpha$ and IL- $1 \beta$ & Rodent & [195] \\
\hline Mechlorethamine-induced nephrotoxicity & Attenuates increase in TNF- $\alpha$ and IL-1 $\beta$ & Rodent & [196] \\
\hline Hypoxia-induced retinal ganglion cell death & Reverses the upregulation of TNF- $\alpha$ and IL- $1 \beta$ & Rodent & [197] \\
\hline Acute lung ischemia-reperfusion injury & Attenuates TNF- $\alpha$ & Rodent & [198] \\
\hline Escherichia-coli-induced pyelonephritis & Attenuates increase in TNF- $\alpha$ & Rodent & [199] \\
\hline Taurocholate-induced acute pancreatitis & Reduces TNF- $\alpha$ & Rodent & [200] \\
\hline $\begin{array}{l}\text { Colitis induced by intracolonic instillation of dinitrobenzene } \\
\text { sulfonic acid }\end{array}$ & Reduces the expression of TNF- $\alpha$ & Rodent & [201] \\
\hline Periodontitis & Reduces TNF- $\alpha$ and IL-1 $\beta$ & Rodent & [202] \\
\hline $\begin{array}{l}\text { Colitis established by intrarectal injection with } \\
\text { 2,4,6-trinitrobenzenesulfonic acid and ethanol }\end{array}$ & Reduces TNF- $\alpha$ and IL-1 $\beta$ & Rodent & [203] \\
\hline Dimethylnitrosamine-induced liver injury & Decreases the expression of TNF- $\alpha$, IL- $1 \beta$, and IL- 6 & Rodent & [204] \\
\hline Hemorrhagic shock & Suppresses the release of TNF- $\alpha$ and IL- 6 & Rodent & [205] \\
\hline Acetic-acid-induced colitis & Attenuates increases in TNF- $\alpha$, IL- $1 \beta$, and IL- 6 & Rodent & [206] \\
\hline FK506-induced renal oxidative stress & Reduces TNF- $\alpha$ and IL- 6 & Rodent & [207] \\
\hline Streptozotocin-induced diabetic neuropathy & Reduces elevated levels of TNF- $\alpha$ and IL- 6 & Rodent & [208] \\
\hline Brain-contusion-induced oxidative insult & Reduces upregulation of IL- 6 & Rodent & [209] \\
\hline Zucker diabetic fatty rats & Lowers TNF- $\alpha$, IL- 6 , and CRP & Rodent & [210] \\
\hline Hepatic ischemia-reperfusion injury & Promotes TNF- $\alpha$ and IL- 6 release & Rodent & [211] \\
\hline LPS treatment & Has no effect on TNF- $\alpha$ or IL- $1 \beta$ release & Rodent & [212] \\
\hline
\end{tabular}


Melatonin has also been shown to suppress inflammatory responses through nonimmunological actions, such as antioxidative protection and mitochondrial function preservation, which promote antioxidative processes as well as decrease free radical formation and excessive NO formation [213-226]. Melatonin was reported to inhibit inflammatory cell activation by reducing myeloperoxidase activity [214,227] and suppressing the inflammasome nucleotide-binding oligomerization domain, a leucine-rich family, and the pyrin domain-containing-3 (NLRP3) [228-231]. Although a general association between melatonin and anti-inflammatory effects might be an oversimplification [232], overall, melatonin can have pro-inflammatory properties in immune suppression or basal conditions and anti-inflammatory properties in pro-inflammatory conditions [233-235]. Therefore, disruption of the melatonin system can further contribute to the exacerbation of inflammation in pro-inflammatory conditions, such as in MDD.

\section{Melatonin and the Brain}

Melatonin has been suggested to be a highly neuroprotective substance that can exert cytoprotective effects $[236,237]$ through biological mechanisms that are separate from its immunomodulatory actions, such as regulating oxidative stress, apoptosis, and mitochondrial homeostasis [238]. Melatonin is a potent antioxidant [239] and has been shown to decrease the extracellular level of glutamate [240] to maintain $\mathrm{Ca}_{2}{ }^{+}$homeostasis and prevent $\mathrm{Ca}_{2}{ }^{+}$-dependent cell injury [241]. One study confirmed that melatonin reduced free radical generation by acting on the MT2 [242] and decreased oxidative stress damage by reducing Nox2 and Nox4 expression [243]. In an animal model of Alzheimer's disease (AD) and patients with $\mathrm{AD}$, melatonin was reported to act as a potent antioxidant [37], reduced A $\beta$-mediated oxidative stress and lipid peroxidase [244,245], regulated levels of mRNA that encoded antioxidant enzymes [192], inhibited nicotinamide adenine dinucleotide phosphate oxidase formation, and reduced reactive oxygen species production [246]. In animal models of Parkinson's disease (PD), melatonin was shown to downregulate oxidative stress effects, act as a potent antioxidant [38], interfere with lipid peroxidation in the hippocampus and striatum, inhibit neuronal death in the nigrostriatal area [247], elevate antioxidant enzyme levels in the nigrostriatal pathway [248], counteract mitochondrial oxidative phosphorylation enzyme reduction in the substantia nigra [249], and reduce nigrostriatal dopaminergic degeneration and lipid peroxidation [250].

In animal studies, melatonin has stimulated all stages of neuroplasticity [251], including neurogenesis, synaptogenesis [252-254], axogenesis [255], and dendritogenesis [256]. Melatonin was shown to repair hippocampal dendrite loss by increasing $\mathrm{Ca}_{2}{ }^{+} /$calmodulin levels and activation of $\mathrm{Ca}_{2}{ }^{+} /$calmodulin (CaM)-dependent kinase II [256]. MT2 receptor activation, which induces Akt/GSK-3 $\beta$ /CRMP-2 signaling, mediates functional axonogenesis and synaptic formation in central neurons [255]. In an animal model of sporadic $\mathrm{AD}$, melatonin significantly increased hippocampal synaptic density and the number of excitatory synapses, decreased the number of inhibitory synapses, upregulated pre- and post-synaptic proteins, improved the ultrastructure of neuronal and glial cells, and reduced glial density [257]. Melatonin was also shown to attenuate synaptic dysfunction and reduce astrogliosis [258]. In animal models of ischemia, melatonin promoted the proliferation of endogenous oligodendrocyte progenitor cells, alleviated white matter (WM) damage [259], promoted subsequent myelination in WM [260], and significantly improved WM lesions and gliosis [261]. Melatonin also promoted distal dendritic ramifications in the layer II/III cortical pyramidal cells of rats exposed to toluene vapors [262] and promoted the genesis of CA1 cells in rats with pinealectomy-induced hippocampal cell loss [263].

Disruption of the melatonin system can lead to a decrease in its cytoprotective and neuroprotective effects, which can further contribute to the neurotoxic effects on brain regions involved in emotion regulation and that contribute to symptoms of depression. 


\section{Melatonin and Depression}

Melatonin has been strongly implicated in the pathophysiology of MDD. In a study that investigated the effects of genetic deletion of the MT1 and/or MT2 receptors on depression- and anxiety-like behaviors in $\mathrm{C}_{3} \mathrm{H} / \mathrm{HeN}$ mice, MT1 and/or MT2 receptor deletion reportedly caused a deficit in hedonic and social interaction behavior and increased anxiety-like behavior; the authors suggested that MT1 and/or MT2 melatonin receptor dysregulations were involved in depression and anxiety pathophysiology [264]. One study reported a possible association between the melatonin plasma level and a neuroinflammatory state in depression [265] and a genetic variation in $\mathrm{N}$-acetylserotonin $\mathrm{O}$-methyltransferase, which is a key enzyme in melatonin biosynthesis [266]. A single nucleotide polymorphism, rs713224, located near the brain-expressed melatonin receptor (MTNR1A) gene, was associated with somatic complaints of depression symptoms on the Center for Epidemiological Studies Depression (CES-D) scale [267], indicating that patients with MDD have weaker responses to melatonin [251].

Agomelatine, an MT1 and MT2 agonist and a 5-HT2C and 5-HT2B serotonin receptor antagonist, is used to treat MDD [268] and has been shown to have positive phase-shifting properties, such as inducing sleep phase advancement, body temperature decline, and melatonin onset. The antidepressant effects of agomelatine prompted preclinical research to validate the antidepressant effects of melatonin [251] using numerous studies with animal models of depression, such as the forced swimming test, the tail suspension test, and the chronic mild stress test, and showed evidence for antidepressant-like actions of melatonin [269-273]. These antidepressant-like effects of melatonin have been associated with neurotransmitter systems, such as the serotoninergic, glutamatergic, and GABAergic systems, along with hypothalamic-pituitary-adrenal axis modulation $[269,271,272]$. The antidepressant effects of melatonin remain unclear in human studies, although several studies have reported that melatonin use is beneficial for improving symptoms associated with depression [274,275].

A possible mechanism of melatonin's anti-depressant effects is its ability to modulate neuroplastic responses in the hippocampus. The hippocampus is the most widely studied brain area related to depression, with a wide range of meta-analytic evidence indicating structural and functional abnormalities of the hippocampus in depression [276], and inflammatory processes have been shown to further contribute to structural changes in the hippocampus in depression $[277,278]$. Preclinical evidence has shown that the hippocampus is one of the main targets for melatonin actions in the brain [251], with melatonin promoting distal dendritic ramifications in layer II/III cortical pyramidal cells [262] and preventing hippocampal CA1 and CA3 cell loss [263]. Melatonin has also been shown to stimulate neurogenesis, axogenesis, and dendritogenesis of hippocampal neurons $[254,255,279]$. Agomelatine, which mainly acts on the melatonin receptor, has been reported to modulate hippocampal plasticity in animal models of depression [280-283], similar to other antidepressants. The disruption of the melatonin system that further contributes to the exacerbation of inflammation and decreases in cytoprotective and neuroprotective effects of hippocampal cells might be one of the core mechanisms underlying the pathophysiology of depression.

\section{Conclusions}

The ability of melatonin to suppress inflammatory responses through immunological and non-immunological actions, thus influencing neuro-inflammation and subsequent alterations in brain regions implicated in depression (Figure 1), is supported by its antidepressant-like effects. Furthermore, disturbances in the circadian system and mood symptoms have been widely suggested to precede by years, the emergence of characteristic cognitive and motor symptoms of neurodegenerative diseases, including AD, PD, and Huntington's disease, and contribute to the onset of the disease [284-288]. The therapeutic potential of melatonin has been investigated in neurodegenerative diseases, although the effects on sleep quality and activity rhythms have been inconsistent [289-293], possi- 
bly due to methodological inconsistencies across trials [294]. Future studies that assess the associations between melatonin, immune markers, and alterations of brain structure and function in patients with depression will aid us to not only better understand potential biomarkers of MDD but also gain insight into ways for the early diagnosis and prevention of neurodegenerative diseases. Longitudinal clinical studies that investigate the effects of melatonin on the long-term progression of cognitive and motor symptoms of neurodegenerative diseases and mood symptoms of depressive disorders can provide clues on novel types of pharmacological interventions. A wide variety of ani-inflammatory agents have been investigated for their possible anti-depressant effects, including celecoxib as a cyclooxygenase-2-selective nonsteroidal anti-inflammatory drug [295-297], TNF- $\alpha$ inhibitors [70,298,299], aspirin (acetylsalicylic acid) [300], and minocycline (tetracycline antibiotic) [301]. Further studies on the treatment efficacy of melatonin along with other therapeutic agents that enhance melatonin's anti-inflammatory, anti-oxidant, and cytoprotective properties can help to develop methods to detect and ultimately treat depression.

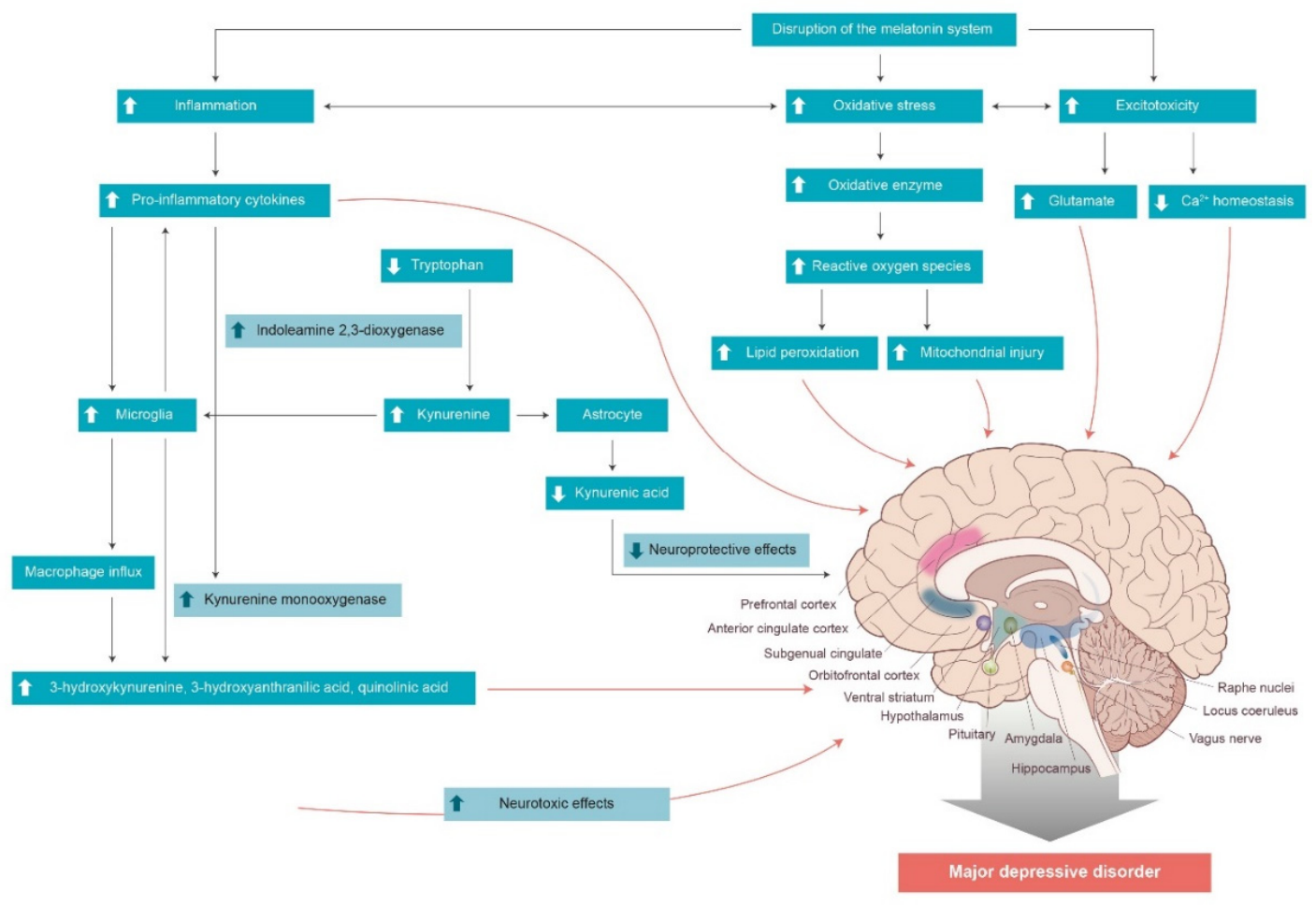

Figure 1. Disruption of the melatonin system can exacerbate inflammatory conditions, which increase neurotoxic metabolites through the kynurenine pathway or directly exert neurotoxic effects on specific brain regions. Disruption of the melatonin system can also lead to oxidative stress and excitotoxicity, further contributing to neuroinflammation, as well as exerting direct neurotoxic effects. Neuroinflammation and subsequent alterations in brain regions involved in emotional regulation have been suggested as an underlying mechanism for the pathophysiology of major depressive disorder.

Author Contributions: E.W., K.-S.N. and Y.-K.K. wrote and reviewed the manuscript. All authors have read and agreed to the published version of the manuscript.

Funding: No external funding was received for this research.

Institutional Review Board Statement: Not applicable.

Informed Consent Statement: Not applicable.

Conflicts of Interest: The authors have no conflict of interest to declare. 


\section{References}

1. Won, E.; Kim, Y.K. Stress, the Autonomic Nervous System, and the Immune-kynurenine Pathway in the Etiology of Depression. Curr. Neuropharmacol. 2016, 14, 665-673. [CrossRef] [PubMed]

2. Muller, N. Immunology of major depression. Neuroimmunomodulation 2014, 21, 123-130. [CrossRef]

3. Kim, Y.K.; Na, K.S.; Shin, K.H.; Jung, H.Y.; Choi, S.H.; Kim, J.B. Cytokine imbalance in the pathophysiology of major depressive disorder. Prog. Neuropsychopharmacol. Biol. Psychiatry 2007, 31, 1044-1053. [CrossRef] [PubMed]

4. Dhabhar, F.S.; Burke, H.M.; Epel, E.S.; Mellon, S.H.; Rosser, R.; Reus, V.I.; Wolkowitz, O.M. Low serum IL-10 concentrations and loss of regulatory association between IL-6 and IL-10 in adults with major depression. J. Psychiatr. Res. 2009, 43, 962-969. [CrossRef]

5. Pepys, M.B.; Hirschfield, G.M. C-reactive protein: A critical update. J. Clin. Investig. 2003, 111, 1805-1812. [CrossRef]

6. Kim, Y.K.; Na, K.S.; Myint, A.M.; Leonard, B.E. The role of pro-inflammatory cytokines in neuroinflammation, neurogenesis and the neuroendocrine system in major depression. Prog. Neuropsychopharmacol. Biol. Psychiatry 2016, 64, 277-284. [CrossRef] [PubMed]

7. Kim, Y.K.; Won, E. The influence of stress on neuroinflammation and alterations in brain structure and function in major depressive disorder. Behav. Brain Res. 2017, 329, 6-11. [CrossRef]

8. Pandi-Perumal, S.R.; Monti, J.M.; Burman, D.; Karthikeyan, R.; BaHammam, A.S.; Spence, D.W.; Brown, G.M.; Narashimhan, M. Clarifying the role of sleep in depression: A narrative review. Psychiatry Res. 2020, 291, 113239. [CrossRef] [PubMed]

9. Satyanarayanan, S.K.; Su, H.; Lin, Y.W.; Su, K.P. Circadian Rhythm and Melatonin in the Treatment of Depression. Curr. Pharm. Des. 2018, 24, 2549-2555. [CrossRef] [PubMed]

10. Hawkins, D.R.; Taub, J.M.; van de Castle, R.L. Extended sleep (hypersomnia) in young depressed patients. Am. J. Psychiatry 1985, $142,905-910$.

11. Armitage, R. Sleep and circadian rhythms in mood disorders. Acta Psychiatr. Scand. Suppl. 2007, 115, 104-115. [CrossRef]

12. Zisapel, N. New perspectives on the role of melatonin in human sleep, circadian rhythms and their regulation. Br. J. Pharmacol. 2018, 175, 3190-3199. [CrossRef] [PubMed]

13. Reynolds, C.F., 3rd; Kupfer, D.J. Sleep research in affective illness: State of the art circa 1987. Sleep 1987, 10, 199-215. [CrossRef]

14. Levi, F.; Schibler, U. Circadian rhythms: Mechanisms and therapeutic implications. Annu. Rev. Pharmacol. Toxicol. 2007, 47, 593-628. [CrossRef]

15. Tonon, A.C.; Pilz, L.K.; Markus, R.P.; Hidalgo, M.P.; Elisabetsky, E. Melatonin and Depression: A Translational Perspective From Animal Models to Clinical Studies. Front. Psychiatry 2021, 12, 638981. [CrossRef] [PubMed]

16. Ashkenazy-Frolinger, T.; Kronfeld-Schor, N.; Juetten, J.; Einat, H. It is darkness and not light: Depression-like behaviors of diurnal unstriped Nile grass rats maintained under a short photoperiod schedule. J. Neurosci. Methods 2010, 186, 165-170. [CrossRef] [PubMed]

17. Deats, S.P.; Adidharma, W.; Yan, L. Hypothalamic dopaminergic neurons in an animal model of seasonal affective disorder. Neurosci. Lett. 2015, 602, 17-21. [CrossRef]

18. Landgraf, D.; Long, J.E.; Proulx, C.D.; Barandas, R.; Malinow, R.; Welsh, D.K. Genetic Disruption of Circadian Rhythms in the Suprachiasmatic Nucleus Causes Helplessness, Behavioral Despair, and Anxiety-like Behavior in Mice. Biol. Psychiatry 2016, 80, 827-835. [CrossRef]

19. Boivin, D.B.; Czeisler, C.A.; Dijk, D.J.; Duffy, J.F.; Folkard, S.; Minors, D.S.; Totterdell, P.; Waterhouse, J.M. Complex interaction of the sleep-wake cycle and circadian phase modulates mood in healthy subjects. Arch. Gen. Psychiatry 1997, 54, 145-152. [CrossRef] [PubMed]

20. Pilz, L.K.; Carissimi, A.; Oliveira, M.A.B.; Francisco, A.P.; Fabris, R.C.; Medeiros, M.S.; Scop, M.; Frey, B.N.; Adan, A.; Hidalgo, M.P. Rhythmicity of Mood Symptoms in Individuals at Risk for Psychiatric Disorders. Sci. Rep. 2018, 8, 11402. [CrossRef] [PubMed]

21. Lewy, A.J. The dim light melatonin onset, melatonin assays and biological rhythm research in humans. Biol. Signals Recept. 1999, 8, 79-83. [CrossRef] [PubMed]

22. Slattery, D.A.; Hudson, A.L.; Nutt, D.J. Invited review: The evolution of antidepressant mechanisms. Fundam. Clin. Pharmacol. 2004, 18, 1-21. [CrossRef] [PubMed]

23. Simonneaux, V.; Ribelayga, C. Generation of the melatonin endocrine message in mammals: A review of the complex regulation of melatonin synthesis by norepinephrine, peptides, and other pineal transmitters. Pharmacol. Rev. 2003, 55, 325-395. [CrossRef] [PubMed]

24. Oglodek, E.A.; Just, M.J.; Szromek, A.R.; Araszkiewicz, A. Melatonin and neurotrophins NT-3, BDNF, NGF in patients with varying levels of depression severity. Pharmacol. Rep. 2016, 68, 945-951. [CrossRef] [PubMed]

25. Sundberg, I.; Ramklint, M.; Stridsberg, M.; Papadopoulos, F.C.; Ekselius, L.; Cunningham, J.L. Salivary Melatonin in Relation to Depressive Symptom Severity in Young Adults. PLoS ONE 2016, 11, e0152814. [CrossRef] [PubMed]

26. Waterman, G.S.; Ryan, N.D.; Perel, J.M.; Dahl, R.E.; Birmaher, B.; Williamson, D.E.; Thomas, C.R.; Puig-Antich, J. Nocturnal urinary excretion of 6-hydroxymelatonin sulfate in prepubertal major depressive disorder. Biol. Psychiatry 1992, 31, 582-590. [CrossRef]

27. Carvalho, L.A.; Gorenstein, C.; Moreno, R.A.; Markus, R.P. Melatonin levels in drug-free patients with major depression from the southern hemisphere. Psychoneuroendocrinology 2006, 31, 761-768. [CrossRef] [PubMed] 
28. Nair, N.P.; Hariharasubramanian, N.; Pilapil, C. Circadian rhythm of plasma melatonin in endogenous depression. Prog. Neuropsychopharmacol. Biol. Psychiatry 1984, 8, 715-718. [CrossRef]

29. Steiner, M.; Brown, G.M.; Goldman, S. Nocturnal melatonin and cortisol secretion in newly admitted psychiatric inpatients. Implications for affective disorders. Eur. Arch. Psychiatry Clin. Neurosci. 1990, 240, 21-27. [CrossRef] [PubMed]

30. Carrillo-Vico, A.; Guerrero, J.M.; Lardone, P.J.; Reiter, R.J. A review of the multiple actions of melatonin on the immune system. Endocrine 2005, 27, 189-200. [CrossRef]

31. Pandi-Perumal, S.R.; Srinivasan, V.; Maestroni, G.J.; Cardinali, D.P.; Poeggeler, B.; Hardeland, R. Melatonin: Nature's most versatile biological signal? FEBS J. 2006, 273, 2813-2838. [CrossRef] [PubMed]

32. Manchester, L.C.; Coto-Montes, A.; Boga, J.A.; Andersen, L.P.; Zhou, Z.; Galano, A.; Vriend, J.; Tan, D.X.; Reiter, R.J. Melatonin: An ancient molecule that makes oxygen metabolically tolerable. J. Pineal Res. 2015, 59, 403-419. [CrossRef]

33. Galano, A.; Tan, D.X.; Reiter, R.J. Melatonin as a natural ally against oxidative stress: A physicochemical examination. J. Pineal Res. 2011, 51, 1-16. [CrossRef]

34. Reiter, R.J.; Tan, D.X.; Rosales-Corral, S.; Galano, A.; Jou, M.J.; Acuna-Castroviejo, D. Melatonin Mitigates Mitochondrial Meltdown: Interactions with SIRT3. Int. J. Mol. Sci. 2018, 19, 2439. [CrossRef] [PubMed]

35. Louzada, P.R.; Paula Lima, A.C.; Mendonca-Silva, D.L.; Noel, F.; de Mello, F.G.; Ferreira, S.T. Taurine prevents the neurotoxicity of beta-amyloid and glutamate receptor agonists: Activation of GABA receptors and possible implications for Alzheimer's disease and other neurological disorders. FASEB J. 2004, 18, 511-518. [CrossRef]

36. Giusti, P.; Lipartiti, M.; Franceschini, D.; Schiavo, N.; Floreani, M.; Manev, H. Neuroprotection by melatonin from kainate-induced excitotoxicity in rats. FASEB J. 1996, 10, 891-896. [CrossRef]

37. Shukla, M.; Govitrapong, P.; Boontem, P.; Reiter, R.J.; Satayavivad, J. Mechanisms of Melatonin in Alleviating Alzheimer's Disease. Curr. Neuropharmacol. 2017, 15, 1010-1031. [CrossRef]

38. Alghamdi, B.S. The neuroprotective role of melatonin in neurological disorders. J. Neurosci. Res. 2018, 96, 1136-1149. [CrossRef]

39. Beni, S.M.; Kohen, R.; Reiter, R.J.; Tan, D.X.; Shohami, E. Melatonin-induced neuroprotection after closed head injury is associated with increased brain antioxidants and attenuated late-phase activation of NF-kappaB and AP-1. FASEB J. 2004, 18, 149-151. [CrossRef]

40. Kabadi, S.V.; Maher, T.J. Posttreatment with uridine and melatonin following traumatic brain injury reduces edema in various brain regions in rats. Ann. N. Y. Acad. Sci. 2010, 1199, 105-113. [CrossRef]

41. Lee, E.J.; Wu, T.S.; Lee, M.Y.; Chen, T.Y.; Tsai, Y.Y.; Chuang, J.I.; Chang, G.L. Delayed treatment with melatonin enhances electrophysiological recovery following transient focal cerebral ischemia in rats. J. Pineal Res. 2004, 36, 33-42. [CrossRef]

42. Jimenez-Ortega, V.; Cano-Barquilla, P.; Scacchi, P.A.; Cardinali, D.P.; Esquifino, A.I. Cadmium-Induced Disruption in 24-h Expression of Clock and Redox Enzyme Genes in Rat Medial Basal Hypothalamus: Prevention by Melatonin. Front. Neurol. 2011, 2, 13. [CrossRef]

43. Poliandri, A.H.; Esquifino, A.I.; Cano, P.; Jimenez, V.; Lafuente, A.; Cardinali, D.P.; Duvilanski, B.H. In vivo protective effect of melatonin on cadmium-induced changes in redox balance and gene expression in rat hypothalamus and anterior pituitary. $J$. Pineal Res. 2006, 41, 238-246. [CrossRef] [PubMed]

44. Princ, F.G.; Juknat, A.A.; Maxit, A.G.; Cardalda, C.; Batlle, A. Melatonin's antioxidant protection against delta-aminolevulinic acid-induced oxidative damage in rat cerebellum. J. Pineal Res. 1997, 23, 40-46. [CrossRef] [PubMed]

45. Shaikh, A.Y.; Xu, J.; Wu, Y.; He, L.; Hsu, C.Y. Melatonin protects bovine cerebral endothelial cells from hyperoxia-induced DNA damage and death. Neurosci. Lett. 1997, 229, 193-197. [CrossRef]

46. Pablos, M.I.; Reiter, R.J.; Chuang, J.I.; Ortiz, G.G.; Guerrero, J.M.; Sewerynek, E.; Agapito, M.T.; Melchiorri, D.; Lawrence, R.; Deneke, S.M. Acutely administered melatonin reduces oxidative damage in lung and brain induced by hyperbaric oxygen. $J$. Appl. Physiol. 1997, 83, 354-358. [CrossRef] [PubMed]

47. Erol, F.S.; Topsakal, C.; Ozveren, M.F.; Kaplan, M.; Ilhan, N.; Ozercan, I.H.; Yildiz, O.G. Protective effects of melatonin and vitamin E in brain damage due to gamma radiation: An experimental study. Neurosurg. Rev. 2004, 27, 65-69. [CrossRef]

48. Reiter, R.J.; Manchester, L.C.; Tan, D.X. Neurotoxins: Free radical mechanisms and melatonin protection. Curr. Neuropharmacol. 2010, 8, 194-210. [CrossRef]

49. Jones, B.E.; Yang, T.Z. The efferent projections from the reticular formation and the locus coeruleus studied by anterograde and retrograde axonal transport in the rat. J. Comp. Neurol. 1985, 242, 56-92. [CrossRef] [PubMed]

50. Lewis, D.I.; Coote, J.H. Excitation and inhibition of rat sympathetic preganglionic neurones by catecholamines. Brain Res. 1990 530, 229-234. [CrossRef]

51. Unnerstall, J.R.; Kopajtic, T.A.; Kuhar, M.J. Distribution of alpha 2 agonist binding sites in the rat and human central nervous system: Analysis of some functional, anatomic correlates of the pharmacologic effects of clonidine and related adrenergic agents. Brain Res. 1984, 319, 69-101. [CrossRef]

52. Rees, C.A. Lost among the trees? The autonomic nervous system and paediatrics. Arch. Dis. Child. 2014, 99, 552-562. [CrossRef]

53. Tsigos, C.; Chrousos, G.P. Hypothalamic-pituitary-adrenal axis, neuroendocrine factors and stress. J. Psychosom. Res. 2002, 53, 865-871. [CrossRef]

54. Wank, S.A. Cholecystokinin receptors. Am. J. Physiol. 1995, 269, G628-G646. [CrossRef]

55. Berecek, K.H.; Brody, M.J. Evidence for a neurotransmitter role for epinephrine derived from the adrenal medulla. Am. J. Physiol. 1982, 242, H593-H601. [CrossRef] 
56. Aunis, D. Exocytosis in chromaffin cells of the adrenal medulla. Int. Rev. Cytol. 1998, 181, 213-320.

57. Albuquerque, E.X.; Pereira, E.F.; Alkondon, M.; Rogers, S.W. Mammalian nicotinic acetylcholine receptors: From structure to function. Physiol. Rev. 2009, 89, 73-120. [CrossRef]

58. Chrousos, G.P.; Gold, P.W. The concepts of stress and stress system disorders. Overview of physical and behavioral homeostasis. JAMA 1992, 267, 1244-1252. [CrossRef] [PubMed]

59. Hasko, G.; Szabo, C. Regulation of cytokine and chemokine production by transmitters and co-transmitters of the autonomic nervous system. Biochem. Pharmacol. 1998, 56, 1079-1087. [CrossRef]

60. Bertini, R.; Garattini, S.; Delgado, R.; Ghezzi, P. Pharmacological activities of chlorpromazine involved in the inhibition of tumour necrosis factor production in vivo in mice. Immunology 1993, 79, 217-219.

61. Spengler, R.N.; Chensue, S.W.; Giacherio, D.A.; Blenk, N.; Kunkel, S.L. Endogenous norepinephrine regulates tumor necrosis factor-alpha production from macrophages in vitro. J. Immunol. 1994, 152, 3024-3031. [PubMed]

62. Chrousos, G.P. The stress response and immune function: Clinical implications. The 1999 Novera H. Spector Lecture. Ann. N. Y. Acad. Sci. 2000, 917, 38-67. [CrossRef]

63. Koff, W.C.; Dunegan, M.A. Modulation of macrophage-mediated tumoricidal activity by neuropeptides and neurohormones. J. Immunol. 1985, 135, 350-354.

64. Borovikova, L.V.; Ivanova, S.; Zhang, M.; Yang, H.; Botchkina, G.I.; Watkins, L.R.; Wang, H.; Abumrad, N.; Eaton, J.W.; Tracey, K.J. Vagus nerve stimulation attenuates the systemic inflammatory response to endotoxin. Nature 2000, 405, 458-462. [CrossRef]

65. Pavlov, V.A.; Parrish, W.R.; Rosas-Ballina, M.; Ochani, M.; Puerta, M.; Ochani, K.; Chavan, S.; Al-Abed, Y.; Tracey, K.J. Brain acetylcholinesterase activity controls systemic cytokine levels through the cholinergic anti-inflammatory pathway. Brain Behav. Immun. 2009, 23, 41-45. [CrossRef]

66. Kent, S.; Bluthe, R.M.; Kelley, K.W.; Dantzer, R. Sickness behavior as a new target for drug development. Trends Pharmacol. Sci. 1992, 13, 24-28. [CrossRef]

67. Meyers, C.A. Mood and cognitive disorders in cancer patients receiving cytokine therapy. Adv. Exp. Med. Biol. 1999, 461, 75-81.

68. Capuron, L.; Ravaud, A.; Dantzer, R. Early depressive symptoms in cancer patients receiving interleukin 2 and/or interferon alfa-2b therapy. J. Clin. Oncol. 2000, 18, 2143-2151. [CrossRef]

69. Capuron, L.; Ravaud, A.; Miller, A.H.; Dantzer, R. Baseline mood and psychosocial characteristics of patients developing depressive symptoms during interleukin-2 and/or interferon-alpha cancer therapy. Brain Behav. Immun. 2004, 18, 205-213. [CrossRef]

70. Tyring, S.; Gottlieb, A.; Papp, K.; Gordon, K.; Leonardi, C.; Wang, A.; Lalla, D.; Woolley, M.; Jahreis, A.; Zitnik, R.; et al. Etanercept and clinical outcomes, fatigue, and depression in psoriasis: Double-blind placebo-controlled randomised phase III trial. Lancet 2006, 367, 29-35. [CrossRef]

71. Kohler-Forsberg, O.; Buttenschon, H.N.; Tansey, K.E.; Maier, W.; Hauser, J.; Dernovsek, M.Z.; Henigsberg, N.; Souery, D.; Farmer, A.; Rietschel, M.; et al. Association between C-reactive protein (CRP) with depression symptom severity and specific depressive symptoms in major depression. Brain Behav. Immun. 2017, 62, 344-350. [CrossRef]

72. De Berardis, D.; Campanella, D.; Gambi, F.; la Rovere, R.; Carano, A.; Conti, C.M.; Sivestrini, C.; Serroni, N.; Piersanti, D.; di Giuseppe, B.; et al. The role of C-reactive protein in mood disorders. Int. J. Immunopathol. Pharmacol. 2006, 19, 721-725. [CrossRef]

73. De Berardis, D.; Fornaro, M.; Orsolini, L.; Iasevoli, F.; Tomasetti, C.; de Bartolomeis, A.; Serroni, N.; de Lauretis, I.; Girinelli, G.; Mazza, M.; et al. Effect of agomelatine treatment on C-reactive protein levels in patients with major depressive disorder: An exploratory study in "real-world" everyday clinical practice. CNS Spectr. 2017, 22, 342-347. [CrossRef] [PubMed]

74. Maddison, D.C.; Giorgini, F. The kynurenine pathway and neurodegenerative disease. Semin. Cell Dev. Biol. 2015, 40, 134-141. [CrossRef] [PubMed]

75. Lugo-Huitron, R.; Blanco-Ayala, T.; Ugalde-Muniz, P.; Carrillo-Mora, P.; Pedraza-Chaverri, J.; Silva-Adaya, D.; Maldonado, P.D.; Torres, I.; Pinzon, E.; Ortiz-Islas, E.; et al. On the antioxidant properties of kynurenic acid: Free radical scavenging activity and inhibition of oxidative stress. Neurotoxicol. Teratol. 2011, 33, 538-547. [CrossRef] [PubMed]

76. Vazquez, S.; Garner, B.; Sheil, M.M.; Truscott, R.J. Characterisation of the major autoxidation products of 3-hydroxykynurenine under physiological conditions. Free Radic. Res. 2000, 32, 11-23. [CrossRef]

77. Okuda, S.; Nishiyama, N.; Saito, H.; Katsuki, H. 3-Hydroxykynurenine, an endogenous oxidative stress generator, causes neuronal cell death with apoptotic features and region selectivity. J. Neurochem. 1998, 70, 299-307. [CrossRef]

78. Goldstein, L.E.; Leopold, M.C.; Huang, X.; Atwood, C.S.; Saunders, A.J.; Hartshorn, M.; Lim, J.T.; Faget, K.Y.; Muffat, J.A.; Scarpa, R.C.; et al. 3-Hydroxykynurenine and 3-hydroxyanthranilic acid generate hydrogen peroxide and promote alpha-crystallin cross-linking by metal ion reduction. Biochemistry 2000, 39, 7266-7275. [CrossRef]

79. Tavares, R.G.; Tasca, C.I.; Santos, C.E.; Alves, L.B.; Porciuncula, L.O.; Emanuelli, T.; Souza, D.O. Quinolinic acid stimulates synaptosomal glutamate release and inhibits glutamate uptake into astrocytes. Neurochem. Int. 2002, 40, 621-627. [CrossRef]

80. Ting, K.K.; Brew, B.J.; Guillemin, G.J. Effect of quinolinic acid on human astrocytes morphology and functions: Implications in Alzheimer's disease. J. Neuroinflamm. 2009, 6, 36. [CrossRef] [PubMed]

81. Perez-De La Cruz, V.; Carrillo-Mora, P.; Santamaria, A. Quinolinic acid, an endogenous molecule combining excitotoxicity, oxidative stress and other toxic mechanisms. Int. J. Tryptophan Res. 2012, 5, 1-8. 
82. Barrientos, R.M.; Sprunger, D.B.; Campeau, S.; Higgins, E.A.; Watkins, L.R.; Rudy, J.W.; Maier, S.F. Brain-derived neurotrophic factor mRNA downregulation produced by social isolation is blocked by intrahippocampal interleukin-1 receptor antagonist. Neuroscience 2003, 121, 847-853. [CrossRef]

83. Ben Menachem-Zidon, O.; Goshen, I.; Kreisel, T.; Ben Menahem, Y.; Reinhartz, E.; Ben Hur, T.; Yirmiya, R. Intrahippocampal transplantation of transgenic neural precursor cells overexpressing interleukin-1 receptor antagonist blocks chronic isolationinduced impairment in memory and neurogenesis. Neuropsychopharmacology 2008, 33, 2251-2262. [CrossRef] [PubMed]

84. Wu, C.W.; Chen, Y.C.; Yu, L.; Chen, H.I.; Jen, C.J.; Huang, A.M.; Tsai, H.J.; Chang, Y.T.; Kuo, Y.M. Treadmill exercise counteracts the suppressive effects of peripheral lipopolysaccharide on hippocampal neurogenesis and learning and memory. J. Neurochem. 2007, 103, 2471-2481. [CrossRef] [PubMed]

85. Koo, J.W.; Duman, R.S. IL-1beta is an essential mediator of the antineurogenic and anhedonic effects of stress. Proc. Natl. Acad. Sci. USA 2008, 105, 751-756. [CrossRef] [PubMed]

86. Ida, T.; Hara, M.; Nakamura, Y.; Kozaki, S.; Tsunoda, S.; Ihara, H. Cytokine-induced enhancement of calcium-dependent glutamate release from astrocytes mediated by nitric oxide. Neurosci. Lett. 2008, 432, 232-236. [CrossRef]

87. Haydon, P.G.; Carmignoto, G. Astrocyte control of synaptic transmission and neurovascular coupling. Physiol. Rev. 2006, 86, 1009-1031. [CrossRef]

88. Savitz, J.; Drevets, W.C.; Smith, C.M.; Victor, T.A.; Wurfel, B.E.; Bellgowan, P.S.; Bodurka, J.; Teague, T.K.; Dantzer, R. Putative neuroprotective and neurotoxic kynurenine pathway metabolites are associated with hippocampal and amygdalar volumes in subjects with major depressive disorder. Neuropsychopharmacology 2015, 40, 463-471. [CrossRef] [PubMed]

89. Frodl, T.; Carballedo, A.; Hughes, M.M.; Saleh, K.; Fagan, A.; Skokauskas, N.; McLoughlin, D.M.; Meaney, J.; O’Keane, V.; Connor, T.J. Reduced expression of glucocorticoid-inducible genes GILZ and SGK-1: High IL-6 levels are associated with reduced hippocampal volumes in major depressive disorder. Transl. Psychiatry 2012, 2, e88. [CrossRef] [PubMed]

90. Su, L.; Faluyi, Y.O.; Hong, Y.T.; Fryer, T.D.; Mak, E.; Gabel, S.; Hayes, L.; Soteriades, S.; Williams, G.B.; Arnold, R.; et al. Neuroinflammatory and morphological changes in late-life depression: The NIMROD study. Br. J. Psychiatry 2016, 209, 525-526. [CrossRef] [PubMed]

91. Felger, J.C.; Li, Z.; Haroon, E.; Woolwine, B.J.; Jung, M.Y.; Hu, X.; Miller, A.H. Inflammation is associated with decreased functional connectivity within corticostriatal reward circuitry in depression. Mol. Psychiatry 2016, 21, 1358-1365. [CrossRef]

92. Boutin, J.A.; Witt-Enderby, P.A.; Sotriffer, C.; Zlotos, D.P. Melatonin receptor ligands: A pharmaco-chemical perspective. J. Pineal Res. 2020, 69, e12672. [CrossRef]

93. Slominski, A.; Wortsman, J.; Tobin, D.J. The cutaneous serotoninergic/melatoninergic system: Securing a place under the sun. FASEB J. 2005, 19, 176-194. [CrossRef]

94. Reiter, R.J.; Richardson, B.A.; Matthews, S.A.; Lane, S.J.; Ferguson, B.N. Rhythms in immunoreactive melatonin in the retina and Harderian gland of rats: Persistence after pinealectomy. Life Sci. 1983, 32, 1229-1236. [CrossRef]

95. Carrillo-Vico, A.; Calvo, J.R.; Abreu, P.; Lardone, P.J.; Garcia-Maurino, S.; Reiter, R.J.; Guerrero, J.M. Evidence of melatonin synthesis by human lymphocytes and its physiological significance: Possible role as intracrine, autocrine, and/or paracrine substance. FASEB J. 2004, 18, 537-539. [CrossRef]

96. Champier, J.; Claustrat, B.; Besancon, R.; Eymin, C.; Killer, C.; Jouvet, A.; Chamba, G.; Fevre-Montange, M. Evidence for tryptophan hydroxylase and hydroxy-indol-O-methyl-transferase mRNAs in human blood platelets. Life Sci. 1997, 60, 2191-2197. [CrossRef]

97. Conti, A.; Conconi, S.; Hertens, E.; Skwarlo-Sonta, K.; Markowska, M.; Maestroni, J.M. Evidence for melatonin synthesis in mouse and human bone marrow cells. J. Pineal Res. 2000, 28, 193-202. [CrossRef] [PubMed]

98. Bubenik, G.A. Gastrointestinal melatonin: Localization, function, and clinical relevance. Dig. Dis. Sci. 2002, 47, 2336-2348. [CrossRef] [PubMed]

99. Tordjman, S.; Chokron, S.; Delorme, R.; Charrier, A.; Bellissant, E.; Jaafari, N.; Fougerou, C. Melatonin: Pharmacology, Functions and Therapeutic Benefits. Curr. Neuropharmacol. 2017, 15, 434-443. [CrossRef] [PubMed]

100. Karasek, M.; Winczyk, K. Melatonin in humans. J. Physiol. Pharmacol. 2006, 57, 19-39.

101. Brown, E.N.; Choe, Y.; Shanahan, T.L.; Czeisler, C.A. A mathematical model of diurnal variations in human plasma melatonin levels. Am. J. Physiol. 1997, 272, E506-E516. [CrossRef] [PubMed]

102. Karasek, M. Melatonin, human aging, and age-related diseases. Exp. Gerontol. 2004, 39, 1723-1729. [CrossRef]

103. Axelrod, J.; Weissbach, H. Enzymatic O-methylation of N-acetylserotonin to melatonin. Science 1960, 131, 1312. [CrossRef]

104. Coon, S.L.; Roseboom, P.H.; Baler, R.; Weller, J.L.; Namboodiri, M.A.; Koonin, E.V.; Klein, D.C. Pineal serotonin N-acetyltransferase: Expression cloning and molecular analysis. Science 1995, 270, 1681-1683. [CrossRef] [PubMed]

105. Reiter, R.J. Melatonin: Clinical relevance. Best Pract. Res. Clin. Endocrinol. Metab. 2003, 17, 273-285. [CrossRef]

106. Moore, R.Y. Circadian rhythms: Basic neurobiology and clinical applications. Annu. Rev. Med. 1997, 48, 253-266. [CrossRef]

107. Ekmekcioglu, C. Melatonin receptors in humans: Biological role and clinical relevance. Biomed. Pharmacother. 2006, 60, 97-108. [CrossRef]

108. Touitou, Y. Melatonin: Hormone and medication. C. R. Seances Soc. Biol. Fil. 1998, 192, 643-657. [PubMed]

109. Brzezinski, A. Melatonin in humans. N. Engl. J. Med. 1997, 336, 186-195. [CrossRef] [PubMed]

110. Hardeland, R.; Poeggeler, B. Non-vertebrate melatonin. J. Pineal Res. 2003, 34, 233-241. [CrossRef] [PubMed] 
111. Foulkes, N.S.; Borjigin, J.; Snyder, S.H.; Sassone-Corsi, P. Rhythmic transcription: The molecular basis of circadian melatonin synthesis. Trends Neurosci. 1997, 20, 487-492. [CrossRef]

112. Liu, L.; Labani, N.; Cecon, E.; Jockers, R. Melatonin Target Proteins: Too Many or Not Enough? Front. Endocrinol. 2019, $10,791$. [CrossRef] [PubMed]

113. Reppert, S.M.; Godson, C.; Mahle, C.D.; Weaver, D.R.; Slaugenhaupt, S.A.; Gusella, J.F. Molecular characterization of a second melatonin receptor expressed in human retina and brain: The Mel1b melatonin receptor. Proc. Natl. Acad. Sci. USA 1995, 92, 8734-8738. [CrossRef] [PubMed]

114. Reppert, S.M.; Tsai, T.; Roca, A.L.; Sauman, I. Cloning of a structural and functional homolog of the circadian clock gene period from the giant silkmoth Antheraea pernyi. Neuron 1994, 13, 1167-1176. [CrossRef]

115. Ebisawa, T.; Karne, S.; Lerner, M.R.; Reppert, S.M. Expression cloning of a high-affinity melatonin receptor from Xenopus dermal melanophores. Proc. Natl. Acad. Sci. USA 1994, 91, 6133-6137. [CrossRef]

116. Dufourny, L.; Levasseur, A.; Migaud, M.; Callebaut, I.; Pontarotti, P.; Malpaux, B.; Monget, P. GPR50 is the mammalian ortholog of Mel1c: Evidence of rapid evolution in mammals. BMC Evol. Biol. 2008, 8, 105. [CrossRef]

117. Dubocovich, M.L.; Delagrange, P.; Krause, D.N.; Sugden, D.; Cardinali, D.P.; Olcese, J. International Union of Basic and Clinical Pharmacology. LXXV. Nomenclature, classification, and pharmacology of G protein-coupled melatonin receptors. Pharmacol. Rev. 2010, 62, 343-380. [CrossRef] [PubMed]

118. Slaugenhaupt, S.A.; Roca, A.L.; Liebert, C.B.; Altherr, M.R.; Gusella, J.F.; Reppert, S.M. Mapping of the gene for the Mel1amelatonin receptor to human chromosome 4 (MTNR1A) and mouse chromosome 8 (Mtnr1a). Genomics 1995, 27, 355-357. [CrossRef]

119. Godson, C.; Reppert, S.M. The Mel1a melatonin receptor is coupled to parallel signal transduction pathways. Endocrinology 1997, 138, 397-404. [CrossRef] [PubMed]

120. Petit, L.; Lacroix, I.; de Coppet, P.; Strosberg, A.D.; Jockers, R. Differential signaling of human Mella and Mel1b melatonin receptors through the cyclic guanosine $3^{\prime}-5^{\prime}$-monophosphate pathway. Biochem. Pharmacol. 1999, 58, 633-639. [CrossRef]

121. Fang, N.; Hu, C.; Sun, W.; Xu, Y.; Gu, Y.; Wu, L.; Peng, Q.; Reiter, R.J.; Liu, L. Identification of a novel melatonin-binding nuclear receptor: Vitamin D receptor. J. Pineal Res. 2020, 68, e12618. [CrossRef] [PubMed]

122. Boutin, J.A.; Ferry, G. Is There Sufficient Evidence that the Melatonin Binding Site MT3 Is Quinone Reductase 2? J. Pharmacol. Exp. Ther. 2019, 368, 59-65. [CrossRef] [PubMed]

123. Rudra, D.S.; Pal, U.; Maiti, N.C.; Reiter, R.J.; Swarnakar, S. Melatonin inhibits matrix metalloproteinase-9 activity by binding to its active site. J. Pineal Res. 2013, 54, 398-405. [CrossRef]

124. Li, X.; Ni, T. Binding of glutathione and melatonin to pepsin occurs via different binding mechanisms. Eur. Biophys. J. 2016, 45, 165-174. [CrossRef] [PubMed]

125. Lajarin-Cuesta, R.; Nanclares, C.; Arranz-Tagarro, J.A.; Gonzalez-Lafuente, L.; Arribas, R.L.; Araujo de Brito, M.; Gandia, L.; de Los Rios, C. Gramine Derivatives Targeting $\mathrm{Ca}(2+)$ Channels and Ser/Thr Phosphatases: A New Dual Strategy for the Treatment of Neurodegenerative Diseases. J. Med. Chem. 2016, 59, 6265-6280. [CrossRef] [PubMed]

126. Jockers, R.; Maurice, P.; Boutin, J.A.; Delagrange, P. Melatonin receptors, heterodimerization, signal transduction and binding sites: What's new? Br. J. Pharmacol. 2008, 154, 1182-1195. [CrossRef] [PubMed]

127. Zawilska, J.B.; Skene, D.J.; Arendt, J. Physiology and pharmacology of melatonin in relation to biological rhythms. Pharmacol. Rep. 2009, 61, 383-410. [CrossRef]

128. Cajochen, C.; Krauchi, K.; Wirz-Justice, A. Role of melatonin in the regulation of human circadian rhythms and sleep. J. Neuroendocrinol. 2003, 15, 432-437. [CrossRef] [PubMed]

129. Lewy, A.J.; Ahmed, S.; Jackson, J.M.; Sack, R.L. Melatonin shifts human circadian rhythms according to a phase-response curve. Chronobiol. Int. 1992, 9, 380-392. [CrossRef]

130. Arendt, J.; Skene, D.J.; Middleton, B.; Lockley, S.W.; Deacon, S. Efficacy of melatonin treatment in jet lag, shift work, and blindness. J. Biol. Rhythms 1997, 12, 604-617. [CrossRef]

131. Sack, R.L.; Brandes, R.W.; Kendall, A.R.; Lewy, A.J. Entrainment of free-running circadian rhythms by melatonin in blind people. N. Engl. J. Med. 2000, 343, 1070-1077. [CrossRef]

132. Zisapel, N. Melatonin-dopamine interactions: From basic neurochemistry to a clinical setting. Cell. Mol. Neurobiol. 2001, 21, 605-616. [CrossRef] [PubMed]

133. Hogan, M.V.; El-Sherif, Y.; Wieraszko, A. The modulation of neuronal activity by melatonin: In vitro studies on mouse hippocampal slices. J. Pineal Res. 2001, 30, 87-96. [CrossRef]

134. Mazzucchelli, C.; Pannacci, M.; Nonno, R.; Lucini, V.; Fraschini, F.; Stankov, B.M. The melatonin receptor in the human brain: Cloning experiments and distribution studies. Brain Res. Mol. Brain Res. 1996, 39, 117-126. [CrossRef]

135. Savaskan, E.; Olivieri, G.; Meier, F.; Brydon, L.; Jockers, R.; Ravid, R.; Wirz-Justice, A.; Muller-Spahn, F. Increased melatonin 1a-receptor immunoreactivity in the hippocampus of Alzheimer's disease patients. J. Pineal Res. 2002, 32, 59-62. [CrossRef]

136. Savaskan, E.; Ayoub, M.A.; Ravid, R.; Angeloni, D.; Fraschini, F.; Meier, F.; Eckert, A.; Muller-Spahn, F.; Jockers, R. Reduced hippocampal MT2 melatonin receptor expression in Alzheimer's disease. J. Pineal Res. 2005, 38, 10-16. [CrossRef]

137. Musshoff, U.; Riewenherm, D.; Berger, E.; Fauteck, J.D.; Speckmann, E.J. Melatonin receptors in rat hippocampus: Molecular and functional investigations. Hippocampus 2002, 12, 165-173. [CrossRef] 
138. Savaskan, E.; Olivieri, G.; Brydon, L.; Jockers, R.; Krauchi, K.; Wirz-Justice, A.; Muller-Spahn, F. Cerebrovascular melatonin MT1-receptor alterations in patients with Alzheimer's disease. Neurosci. Lett. 2001, 308, 9-12. [CrossRef]

139. Anton-Tay, F. Melatonin: Effects on brain function. Adv. Biochem. Psychopharmacol. 1974, 11, 315-324.

140. Jan, J.E.; O'Donnell, M.E. Use of melatonin in the treatment of paediatric sleep disorders. J. Pineal Res. 1996, $21,193-199$. [CrossRef]

141. Molina-Carballo, A.; Munoz-Hoyos, A.; Reiter, R.J.; Sanchez-Forte, M.; Moreno-Madrid, F.; Rufo-Campos, M.; Molina-Font, J.A.; Acuna-Castroviejo, D. Utility of high doses of melatonin as adjunctive anticonvulsant therapy in a child with severe myoclonic epilepsy: Two years' experience. J. Pineal Res. 1997, 23, 97-105. [CrossRef]

142. Mevissen, M.; Ebert, U. Anticonvulsant effects of melatonin in amygdala-kindled rats. Neurosci. Lett. 1998, 257, 13-16. [CrossRef]

143. Fauteck, J.; Schmidt, H.; Lerchl, A.; Kurlemann, G.; Wittkowski, W. Melatonin in epilepsy: First results of replacement therapy and first clinical results. Biol. Signals Recept. 1999, 8, 105-110. [CrossRef] [PubMed]

144. Kabuto, H.; Yokoi, I.; Ogawa, N. Melatonin inhibits iron-induced epileptic discharges in rats by suppressing peroxidation. Epilepsia 1998, 39, 237-243. [CrossRef]

145. Niles, L.P.; Pickering, D.S.; Arciszewski, M.A. Effects of chronic melatonin administration on GABA and diazepam binding in rat brain. J. Neural Transm. 1987, 70, 117-124.

146. Acuna-Castroviejo, D.; Lowenstein, P.R.; Rosenstein, R.; Cardinali, D.P. Diurnal variations of benzodiazepine binding in rat cerebral cortex: Disruption by pinealectomy. J. Pineal Res. 1986, 3, 101-109. [CrossRef] [PubMed]

147. Munoz-Hoyos, A.; Sanchez-Forte, M.; Molina-Carballo, A.; Escames, G.; Martin-Medina, E.; Reiter, R.J.; Molina-Font, J.A.; Acuna-Castroviejo, D. Melatonin's role as an anticonvulsant and neuronal protector: Experimental and clinical evidence. J. Child. Neurol. 1998, 13, 501-509. [CrossRef]

148. Sheldon, S.H. Pro-convulsant effects of oral melatonin in neurologically disabled children. Lancet 1998, 351, 1254. [CrossRef]

149. Carrillo-Vico, A.; Lardone, P.J.; Alvarez-Sanchez, N.; Rodriguez-Rodriguez, A.; Guerrero, J.M. Melatonin: Buffering the immune system. Int. J. Mol. Sci. 2013, 14, 8638-8683. [CrossRef] [PubMed]

150. Withyachumnarnkul, B.; Nonaka, K.O.; Santana, C.; Attia, A.M.; Reiter, R.J. Interferon-gamma modulates melatonin production in rat pineal glands in organ culture. J. Interferon Res. 1990, 10, 403-411. [CrossRef] [PubMed]

151. Pontes, G.N.; Cardoso, E.C.; Carneiro-Sampaio, M.M.; Markus, R.P. Pineal melatonin and the innate immune response: The TNF-alpha increase after cesarean section suppresses nocturnal melatonin production. J. Pineal Res. 2007, 43, 365-371. [CrossRef]

152. Tan, D.X.; Manchester, L.C.; Hardeland, R.; Lopez-Burillo, S.; Mayo, J.C.; Sainz, R.M.; Reiter, R.J. Melatonin: A hormone, a tissue factor, an autocoid, a paracoid, and an antioxidant vitamin. J. Pineal Res. 2003, 34, 75-78. [CrossRef]

153. Martins, E., Jr.; Ferreira, A.C.; Skorupa, A.L.; Afeche, S.C.; Cipolla-Neto, J.; Costa Rosa, L.F. Tryptophan consumption and indoleamines production by peritoneal cavity macrophages. J. Leukoc. Biol. 2004, 75, 1116-1121. [CrossRef]

154. Jimenez-Jorge, S.; Jimenez-Caliani, A.J.; Guerrero, J.M.; Naranjo, M.C.; Lardone, P.J.; Carrillo-Vico, A.; Osuna, C.; Molinero, P. Melatonin synthesis and melatonin-membrane receptor (MT1) expression during rat thymus development: Role of the pineal gland. J. Pineal Res. 2005, 39, 77-83. [CrossRef]

155. Ahmad, R.; Haldar, C. Melatonin and androgen receptor expression interplay modulates cell-mediated immunity in tropical rodent Funambulus pennanti: An in-vivo and in-vitro study. Scand. J. Immunol. 2010, 71, 420-430. [CrossRef]

156. Pozo, D.; Delgado, M.; Fernandez-Santos, J.M.; Calvo, J.R.; Gomariz, R.P.; Martin-Lacave, I.; Ortiz, G.G.; Guerrero, J.M. Expression of the Mella-melatonin receptor mRNA in T and B subsets of lymphocytes from rat thymus and spleen. FASEB J. 1997, 11, 466-473. [CrossRef]

157. Sze, S.F.; Liu, W.K.; Ng, T.B. Stimulation of murine splenocytes by melatonin and methoxytryptamine. J. Neural Transm. Gen. Sect. 1993, 94, 115-126. [CrossRef]

158. Carrillo-Vico, A.; Reiter, R.J.; Lardone, P.J.; Herrera, J.L.; Fernandez-Montesinos, R.; Guerrero, J.M.; Pozo, D. The modulatory role of melatonin on immune responsiveness. Curr. Opin. Investig. Drugs 2006, 7, 423-431.

159. Kaur, C.; Ling, E.A. Effects of melatonin on macrophages/microglia in postnatal rat brain. J. Pineal Res. 1999, 26, 158-168. [CrossRef]

160. Lissoni, P.; Marelli, O.; Mauri, R.; Resentini, M.; Franco, P.; Esposti, D.; Esposti, G.; Fraschini, F.; Halberg, F.; Sothern, R.B.; et al. Ultradian chronomodulation by melatonin of a Placebo effect upon human killer cell activity. Chronobiologia 1986, 13, 339-343.

161. Arias, J.; Melean, E.; Valero, N.; Pons, H.; Chacin-Bonilla, L.; Larreal, Y.; Bonilla, E. Effect of melatonin on lymphocyte proliferation and production of interleukin-2 (IL-2) and interleukin-1 beta (IL-1 beta) in mice splenocytes. Investig. Clin. 2003, 44, 41-50.

162. Garcia-Maurino, S.; Gonzalez-Haba, M.G.; Calvo, J.R.; Rafii-El-Idrissi, M.; Sanchez-Margalet, V.; Goberna, R.; Guerrero, J.M. Melatonin enhances IL-2, IL-6, and IFN-gamma production by human circulating CD4+ cells: A possible nuclear receptormediated mechanism involving $\mathrm{T}$ helper type 1 lymphocytes and monocytes. J. Immunol. 1997, 159, 574-581.

163. Kim, Y.O.; Pyo, M.Y.; Kim, J.H. Influence of melatonin on immunotoxicity of lead. Int. J. Immunopharmacol. 2000, $22,821-832$. [CrossRef]

164. Akbulut, K.G.; Gonul, B.; Akbulut, H. The effects of melatonin on humoral immune responses of young and aged rats. Immunol. Investig. 2001, 30, 17-20. [CrossRef]

165. Inserra, P.; Zhang, Z.; Ardestani, S.K.; Araghi-Niknam, M.; Liang, B.; Jiang, S.; Shaw, D.; Molitor, M.; Elliott, K.; Watson, R.R. Modulation of cytokine production by dehydroepiandrosterone (DHEA) plus melatonin (MLT) supplementation of old mice. Proc. Soc. Exp. Biol. Med. 1998, 218, 76-82. [CrossRef] 
166. Lin, X.J.; Mei, G.P.; Liu, J.; Li, Y.L.; Zuo, D.; Liu, S.J.; Zhao, T.B.; Lin, M.T. Therapeutic effects of melatonin on heatstroke-induced multiple organ dysfunction syndrome in rats. J. Pineal Res. 2011, 50, 436-444. [CrossRef]

167. Lee, M.Y.; Kuan, Y.H.; Chen, H.Y.; Chen, T.Y.; Chen, S.T.; Huang, C.C.; Yang, I.P.; Hsu, Y.S.; Wu, T.S.; Lee, E.J. Intravenous administration of melatonin reduces the intracerebral cellular inflammatory response following transient focal cerebral ischemia in rats. J. Pineal Res. 2007, 42, 297-309. [CrossRef]

168. Deng, W.G.; Tang, S.T.; Tseng, H.P.; Wu, K.K. Melatonin suppresses macrophage cyclooxygenase-2 and inducible nitric oxide synthase expression by inhibiting p52 acetylation and binding. Blood 2006, 108, 518-524. [CrossRef]

169. Veneroso, C.; Tunon, M.J.; Gonzalez-Gallego, J.; Collado, P.S. Melatonin reduces cardiac inflammatory injury induced by acute exercise. J. Pineal Res. 2009, 47, 184-191. [CrossRef]

170. Jung, K.H.; Hong, S.W.; Zheng, H.M.; Lee, H.S.; Lee, H.; Lee, D.H.; Lee, S.Y.; Hong, S.S. Melatonin ameliorates cerulein-induced pancreatitis by the modulation of nuclear erythroid 2-related factor 2 and nuclear factor-kappaB in rats. J. Pineal Res. 2010, 48, 239-250. [CrossRef]

171. Chen, C.F.; Wang, D.; Reiter, R.J.; Yeh, D.Y. Oral melatonin attenuates lung inflammation and airway hyperreactivity induced by inhalation of aerosolized pancreatic fluid in rats. J. Pineal Res. 2011, 50, 46-53. [CrossRef]

172. Tyagi, E.; Agrawal, R.; Nath, C.; Shukla, R. Effect of melatonin on neuroinflammation and acetylcholinesterase activity induced by LPS in rat brain. Eur. J. Pharmacol. 2010, 640, 206-210. [CrossRef] [PubMed]

173. Chahbouni, M.; Escames, G.; Venegas, C.; Sevilla, B.; Garcia, J.A.; Lopez, L.C.; Munoz-Hoyos, A.; Molina-Carballo, A.; AcunaCastroviejo, D. Melatonin treatment normalizes plasma pro-inflammatory cytokines and nitrosative/oxidative stress in patients suffering from Duchenne muscular dystrophy. J. Pineal Res. 2010, 48, 282-289. [CrossRef] [PubMed]

174. Xu, D.X.; Wang, H.; Ning, H.; Zhao, L.; Chen, Y.H. Maternally administered melatonin differentially regulates lipopolysaccharideinduced proinflammatory and anti-inflammatory cytokines in maternal serum, amniotic fluid, fetal liver, and fetal brain. J. Pineal Res. 2007, 43, 74-79. [CrossRef] [PubMed]

175. Paccotti, P.; Terzolo, M.; Piovesan, A.; Torta, M.; Vignani, A.; Angeli, A. Effects of exogenous melatonin on human pituitary and adrenal secretions. Hormonal responses to specific stimuli after acute administration of different doses at two opposite circadian stages in men. Chronobiologia 1988, 15, 279-287. [PubMed]

176. Pena, C.; Rincon, J.; Pedreanez, A.; Viera, N.; Mosquera, J. Chemotactic effect of melatonin on leukocytes. J. Pineal Res. 2007, 43, 263-269. [CrossRef]

177. Pioli, C.; Caroleo, M.C.; Nistico, G.; Doria, G. Melatonin increases antigen presentation and amplifies specific and non specific signals for T-cell proliferation. Int. J. Immunopharmacol. 1993, 15, 463-468. [CrossRef]

178. Rodriguez, A.B.; Terron, M.P.; Duran, J.; Ortega, E.; Barriga, C. Physiological concentrations of melatonin and corticosterone affect phagocytosis and oxidative metabolism of ring dove heterophils. J. Pineal Res. 2001, 31, 31-38. [CrossRef]

179. Wichmann, M.W.; Zellweger, R.; DeMaso, C.M.; Ayala, A.; Chaudry, I.H. Melatonin administration attenuates depressed immune functions trauma-hemorrhage. J. Surg. Res. 1996, 63, 256-262. [CrossRef] [PubMed]

180. Fjaerli, O.; Lund, T.; Osterud, B. The effect of melatonin on cellular activation processes in human blood. J. Pineal Res. 1999, 26, 50-55. [CrossRef]

181. Finocchiaro, L.M.; Arzt, E.S.; Fernandez-Castelo, S.; Criscuolo, M.; Finkielman, S.; Nahmod, V.E. Serotonin and melatonin synthesis in peripheral blood mononuclear cells: Stimulation by interferon-gamma as part of an immunomodulatory pathway. $J$. Interferon Res. 1988, 8, 705-716. [CrossRef]

182. Cao, Z.; Fang, Y.; Lu, Y.; Tan, D.; Du, C.; Li, Y.; Ma, Q.; Yu, J.; Chen, M.; Zhou, C.; et al. Melatonin alleviates cadmium-induced liver injury by inhibiting the TXNIP-NLRP3 inflammasome. J. Pineal Res. 2017, 62, e12389. [CrossRef] [PubMed]

183. Laliena, A.; San Miguel, B.; Crespo, I.; Alvarez, M.; Gonzalez-Gallego, J.; Tunon, M.J. Melatonin attenuates inflammation and promotes regeneration in rabbits with fulminant hepatitis of viral origin. J. Pineal Res. 2012, 53, 270-278. [CrossRef] [PubMed]

184. Kleber, A.; Altmeyer, S.; Wolf, B.; Wolf, A.; Volk, T.; Fink, T.; Kubulus, D. Impact of melatonin receptor deletion on intracellular signaling in spleen cells of mice after polymicrobial sepsis. Inflamm. Res. 2014, 63, 1023-1033. [CrossRef]

185. Jaworek, J.; Szklarczyk, J.; Jaworek, A.K.; Nawrot-Porabka, K.; Leja-Szpak, A.; Bonior, J.; Kot, M. Protective effect of melatonin on acute pancreatitis. Int. J. Inflamm. 2012, 2012, 173675. [CrossRef] [PubMed]

186. Lotufo, C.M.; Yamashita, C.E.; Farsky, S.H.; Markus, R.P. Melatonin effect on endothelial cells reduces vascular permeability increase induced by leukotriene B4. Eur. J. Pharmacol. 2006, 534, 258-263. [CrossRef]

187. Min, K.J.; Jang, J.H.; Kwon, T.K. Inhibitory effects of melatonin on the lipopolysaccharide-induced CC chemokine expression in BV2 murine microglial cells are mediated by suppression of Akt-induced NF-kappaB and STAT/GAS activity. J. Pineal Res. 2012, 52, 296-304. [CrossRef] [PubMed]

188. Kim, G.D.; Lee, S.E.; Kim, T.H.; Jin, Y.H.; Park, Y.S.; Park, C.S. Melatonin suppresses acrolein-induced IL-8 production in human pulmonary fibroblasts. J. Pineal Res. 2012, 52, 356-364. [CrossRef] [PubMed]

189. Silva, S.O.; Rodrigues, M.R.; Ximenes, V.F.; Bueno-da-Silva, A.E.; Amarante-Mendes, G.P.; Campa, A. Neutrophils as a specific target for melatonin and kynuramines: Effects on cytokine release. J. Neuroimmunol. 2004, 156, 146-152. [CrossRef] [PubMed]

190. Gitto, E.; Reiter, R.J.; Cordaro, S.P.; la Rosa, M.; Chiurazzi, P.; Trimarchi, G.; Gitto, P.; Calabro, M.P.; Barberi, I. Oxidative and inflammatory parameters in respiratory distress syndrome of preterm newborns: Beneficial effects of melatonin. Am. J. Perinatol. 2004, 21, 209-216. [CrossRef] [PubMed] 
191. Gitto, E.; Aversa, S.; Salpietro, C.D.; Barberi, I.; Arrigo, T.; Trimarchi, G.; Reiter, R.J.; Pellegrino, S. Pain in neonatal intensive care: Role of melatonin as an analgesic antioxidant. J. Pineal Res. 2012, 52, 291-295. [CrossRef] [PubMed]

192. Olcese, J.M.; Cao, C.; Mori, T.; Mamcarz, M.B.; Maxwell, A.; Runfeldt, M.J.; Wang, L.; Zhang, C.; Lin, X.; Zhang, G.; et al. Protection against cognitive deficits and markers of neurodegeneration by long-term oral administration of melatonin in a transgenic model of Alzheimer disease. J. Pineal Res. 2009, 47, 82-96. [CrossRef] [PubMed]

193. Ganguly, K.; Swarnakar, S. Chronic gastric ulceration causes matrix metalloproteinases-9 and -3 augmentation: Alleviation by melatonin. Biochimie 2012, 94, 2687-2698. [CrossRef] [PubMed]

194. Jang, S.S.; Kim, H.G.; Lee, J.S.; Han, J.M.; Park, H.J.; Huh, G.J.; Son, C.G. Melatonin reduces X-ray radiation-induced lung injury in mice by modulating oxidative stress and cytokine expression. Int. J. Radiat. Biol. 2013, 89, 97-105. [CrossRef] [PubMed]

195. Wang, H.; Wei, W.; Zhang, S.Y.; Shen, Y.X.; Yue, L.; Wang, N.P.; Xu, S.Y. Melatonin-selenium nanoparticles inhibit oxidative stress and protect against hepatic injury induced by Bacillus Calmette-Guerin/lipopolysaccharide in mice. J. Pineal Res. 2005, 39, 156-163. [CrossRef] [PubMed]

196. Kunak, Z.I.; Macit, E.; Yaren, H.; Yaman, H.; Cakir, E.; Aydin, I.; Turker, T.; Kurt, Y.G.; Ozcan, A.; Uysal, B.; et al. Protective effects of melatonin and S-methylisothiourea on mechlorethamine induced nephrotoxicity. J. Surg. Res. 2012, 175, e17-e23. [CrossRef] [PubMed]

197. Kaur, C.; Sivakumar, V.; Robinson, R.; Foulds, W.S.; Luu, C.D.; Ling, E.A. Neuroprotective effect of melatonin against hypoxiainduced retinal ganglion cell death in neonatal rats. J. Pineal Res. 2013, 54, 190-206. [CrossRef]

198. Yip, H.K.; Chang, Y.C.; Wallace, C.G.; Chang, L.T.; Tsai, T.H.; Chen, Y.L.; Chang, H.W.; Leu, S.; Zhen, Y.Y.; Tsai, C.Y.; et al. Melatonin treatment improves adipose-derived mesenchymal stem cell therapy for acute lung ischemia-reperfusion injury. J. Pineal Res. 2013, 54, 207-221. [CrossRef]

199. Sener, G.; Tugtepe, H.; Velioglu-Ogunc, A.; Cetinel, S.; Gedik, N.; Yegen, B.C. Melatonin prevents neutrophil-mediated oxidative injury in Escherichia coli-induced pyelonephritis in rats. J. Pineal Res. 2006, 41, 220-227. [CrossRef] [PubMed]

200. Gulben, K.; Ozdemir, H.; Berberoglu, U.; Mersin, H.; Yrkin, F.; Cakyr, E.; Aksaray, S. Melatonin modulates the severity of taurocholate-induced acute pancreatitis in the rat. Dig. Dis. Sci. 2010, 55, 941-946. [CrossRef]

201. Mazzon, E.; Esposito, E.; Crisafulli, C.; Riccardi, L.; Muia, C.; di Bella, P.; Meli, R.; Cuzzocrea, S. Melatonin modulates signal transduction pathways and apoptosis in experimental colitis. J. Pineal Res. 2006, 41, 363-373. [CrossRef]

202. Kara, A.; Akman, S.; Ozkanlar, S.; Tozoglu, U.; Kalkan, Y.; Canakci, C.F.; Tozoglu, S. Immune modulatory and antioxidant effects of melatonin in experimental periodontitis in rats. Free Radic. Biol. Med. 2013, 55, 21-26. [CrossRef]

203. Mei, Q.; Yu, J.P.; Xu, J.M.; Wei, W.; Xiang, L.; Yue, L. Melatonin reduces colon immunological injury in rats by regulating activity of macrophages. Acta Pharmacol. Sin. 2002, 23, 882-886.

204. Jung, K.H.; Hong, S.W.; Zheng, H.M.; Lee, D.H.; Hong, S.S. Melatonin downregulates nuclear erythroid 2-related factor 2 and nuclear factor-kappaB during prevention of oxidative liver injury in a dimethylnitrosamine model. J. Pineal Res. 2009, 47, 173-183. [CrossRef]

205. Yang, F.L.; Subeq, Y.M.; Lee, C.J.; Lee, R.P.; Peng, T.C.; Hsu, B.G. Melatonin ameliorates hemorrhagic shock-induced organ damage in rats. J. Surg. Res. 2011, 167, e315-e321. [CrossRef]

206. Tahan, G.; Gramignoli, R.; Marongiu, F.; Aktolga, S.; Cetinkaya, A.; Tahan, V.; Dorko, K. Melatonin expresses powerful antiinflammatory and antioxidant activities resulting in complete improvement of acetic-acid-induced colitis in rats. Dig. Dis. Sci. 2011, 56, 715-720. [CrossRef] [PubMed]

207. Ara, C.; Dirican, A.; Unal, B.; Bay Karabulut, A.; Piskin, T. The effect of melatonin against FK506-induced renal oxidative stress in rats. Surg. Innov. 2011, 18, 34-38. [CrossRef] [PubMed]

208. Negi, G.; Kumar, A.; Sharma, S.S. Melatonin modulates neuroinflammation and oxidative stress in experimental diabetic neuropathy: Effects on NF-kappaB and Nrf2 cascades. J. Pineal Res. 2011, 50, 124-131. [CrossRef]

209. Tsai, M.C.; Chen, W.J.; Tsai, M.S.; Ching, C.H.; Chuang, J.I. Melatonin attenuates brain contusion-induced oxidative insult, inactivation of signal transducers and activators of transcription 1, and upregulation of suppressor of cytokine signaling-3 in rats. J. Pineal Res. 2011, 51, 233-245. [CrossRef] [PubMed]

210. Agil, A.; Reiter, R.J.; Jimenez-Aranda, A.; Iban-Arias, R.; Navarro-Alarcon, M.; Marchal, J.A.; Adem, A.; Fernandez-Vazquez, G. Melatonin ameliorates low-grade inflammation and oxidative stress in young Zucker diabetic fatty rats. J. Pineal Res. 2013, 54, 381-388. [CrossRef]

211. Song, Z.; Humar, B.; Gupta, A.; Maurizio, E.; Borgeaud, N.; Graf, R.; Clavien, P.A.; Tian, Y. Exogenous melatonin protects small-for-size liver grafts by promoting monocyte infiltration and releases interleukin-6. J. Pineal Res. 2018, 65, e12486. [CrossRef] [PubMed]

212. Shafer, L.L.; McNulty, J.A.; Young, M.R. Assessment of melatonin's ability to regulate cytokine production by macrophage and microglia cell types. J. Neuroimmunol. 2001, 120, 84-93. [CrossRef]

213. Leon, J.; Acuna-Castroviejo, D.; Escames, G.; Tan, D.X.; Reiter, R.J. Melatonin mitigates mitochondrial malfunction. J. Pineal Res. 2005, 38, 1-9. [CrossRef] [PubMed]

214. Sener, G.; Toklu, H.; Kapucu, C.; Ercan, F.; Erkanli, G.; Kacmaz, A.; Tilki, M.; Yegen, B.C. Melatonin protects against oxidative organ injury in a rat model of sepsis. Surg. Today 2005, 35, 52-59. [CrossRef] 
215. Lopez, L.C.; Escames, G.; Tapias, V.; Utrilla, P.; Leon, J.; Acuna-Castroviejo, D. Identification of an inducible nitric oxide synthase in diaphragm mitochondria from septic mice: Its relation with mitochondrial dysfunction and prevention by melatonin. Int. J. Biochem. Cell Biol. 2006, 38, 267-278. [CrossRef]

216. Escames, G.; Lopez, L.C.; Tapias, V.; Utrilla, P.; Reiter, R.J.; Hitos, A.B.; Leon, J.; Rodriguez, M.I.; Acuna-Castroviejo, D. Melatonin counteracts inducible mitochondrial nitric oxide synthase-dependent mitochondrial dysfunction in skeletal muscle of septic mice. J. Pineal Res. 2006, 40, 71-78. [CrossRef]

217. Escames, G.; Acuna-Castroviejo, D.; Lopez, L.C.; Tan, D.X.; Maldonado, M.D.; Sanchez-Hidalgo, M.; Leon, J.; Reiter, R.J. Pharmacological utility of melatonin in the treatment of septic shock: Experimental and clinical evidence. J. Pharm. Pharmacol. 2006, 58, 1153-1165. [CrossRef]

218. Ozdemir, D.; Uysal, N.; Tugyan, K.; Gonenc, S.; Acikgoz, O.; Aksu, I.; Ozkan, H. The effect of melatonin on endotoxemia-induced intestinal apoptosis and oxidative stress in infant rats. Intensive Care Med. 2007, 33, 511-516. [CrossRef]

219. De Filippis, D.; Iuvone, T.; Esposito, G.; Steardo, L.; Arnold, G.H.; Paul, A.P.; de Man Joris, G.; de Winter Benedicte, Y. Melatonin reverses lipopolysaccharide-induced gastro-intestinal motility disturbances through the inhibition of oxidative stress. J. Pineal Res. 2008, 44, 45-51. [CrossRef]

220. Lowes, D.A.; Almawash, A.M.; Webster, N.R.; Reid, V.L.; Galley, H.F. Melatonin and structurally similar compounds have differing effects on inflammation and mitochondrial function in endothelial cells under conditions mimicking sepsis. Br. $J$. Anaesth. 2011, 107, 193-201. [CrossRef] [PubMed]

221. Zhang, H.; Liu, D.; Wang, X.; Chen, X.; Long, Y.; Chai, W.; Zhou, X.; Rui, X.; Zhang, Q.; Wang, H.; et al. Melatonin improved rat cardiac mitochondria and survival rate in septic heart injury. J. Pineal Res. 2013, 55, 1-6. [CrossRef] [PubMed]

222. Alamili, M.; Klein, M.; Lykkesfeldt, J.; Rosenberg, J.; Gogenur, I. Circadian variation in the response to experimental endotoxemia and modulatory effects of exogenous melatonin. Chronobiol. Int. 2013, 30, 1174-1180. [CrossRef] [PubMed]

223. Ortiz, F.; Garcia, J.A.; Acuna-Castroviejo, D.; Doerrier, C.; Lopez, A.; Venegas, C.; Volt, H.; Luna-Sanchez, M.; Lopez, L.C.; Escames, G. The beneficial effects of melatonin against heart mitochondrial impairment during sepsis: Inhibition of iNOS and preservation of nNOS. J. Pineal Res. 2014, 56, 71-81. [CrossRef]

224. Kleber, A.; Kubulus, D.; Rossler, D.; Wolf, B.; Volk, T.; Speer, T.; Fink, T. Melatonin modifies cellular stress in the liver of septic mice by reducing reactive oxygen species and increasing the unfolded protein response. Exp. Mol. Pathol. 2014, 97, 565-571. [CrossRef] [PubMed]

225. Acuna-Castroviejo, D.; Rahim, I.; Acuna-Fernandez, C.; Fernandez-Ortiz, M.; Solera-Marin, J.; Sayed, R.K.A.; Diaz-Casado, M.E.; Rusanova, I.; Lopez, L.C.; Escames, G. Melatonin, clock genes and mitochondria in sepsis. Cell. Mol. Life Sci. 2017, 74, 3965-3987. [CrossRef] [PubMed]

226. An, R.; Zhao, L.; Xi, C.; Li, H.; Shen, G.; Liu, H.; Zhang, S.; Sun, L. Melatonin attenuates sepsis-induced cardiac dysfunction via a PI3K/Akt-dependent mechanism. Basic Res. Cardiol. 2016, 111, 8. [CrossRef] [PubMed]

227. Shang, Y.; Xu, S.P.; Wu, Y.; Jiang, Y.X.; Wu, Z.Y.; Yuan, S.Y.; Yao, S.L. Melatonin reduces acute lung injury in endotoxemic rats. Chin. Med. J. 2009, 122, 1388-1393.

228. Ortiz, F.; Acuna-Castroviejo, D.; Doerrier, C.; Dayoub, J.C.; Lopez, L.C.; Venegas, C.; Garcia, J.A.; Lopez, A.; Volt, H.; Luna-Sanchez M.; et al. Melatonin blunts the mitochondrial/NLRP3 connection and protects against radiation-induced oral mucositis. J. Pineal Res. 2015, 58, 34-49. [CrossRef] [PubMed]

229. Garcia, J.A.; Volt, H.; Venegas, C.; Doerrier, C.; Escames, G.; Lopez, L.C.; Acuna-Castroviejo, D. Disruption of the NFkappaB/NLRP3 connection by melatonin requires retinoid-related orphan receptor-alpha and blocks the septic response in mice. FASEB J. 2015, 29, 3863-3875. [CrossRef]

230. Volt, H.; Garcia, J.A.; Doerrier, C.; Diaz-Casado, M.E.; Guerra-Librero, A.; Lopez, L.C.; Escames, G.; Tresguerres, J.A.; AcunaCastroviejo, D. Same molecule but different expression: Aging and sepsis trigger NLRP3 inflammasome activation, a target of melatonin. J. Pineal Res. 2016, 60, 193-205. [CrossRef]

231. Dong, Y.; Fan, C.; Hu, W.; Jiang, S.; Ma, Z.; Yan, X.; Deng, C.; Di, S.; Xin, Z.; Wu, G.; et al. Melatonin attenuated early brain injury induced by subarachnoid hemorrhage via regulating NLRP3 inflammasome and apoptosis signaling. J. Pineal Res. 2016, 60, 253-262. [CrossRef] [PubMed]

232. Hardeland, R. Melatonin and inflammation-Story of a double-edged blade. J. Pineal Res. 2018, 65, e12525. [CrossRef] [PubMed]

233. Alvarez-Sanchez, N.; Cruz-Chamorro, I.; Lopez-Gonzalez, A.; Utrilla, J.C.; Fernandez-Santos, J.M.; Martinez-Lopez, A.; Lardone, P.J.; Guerrero, J.M.; Carrillo-Vico, A. Melatonin controls experimental autoimmune encephalomyelitis by altering the T effector/regulatory balance. Brain Behav. Immun. 2015, 50, 101-114. [CrossRef]

234. Alvarez-Sanchez, N.; Cruz-Chamorro, I.; Diaz-Sanchez, M.; Sarmiento-Soto, H.; Medrano-Campillo, P.; Martinez-Lopez, A.; Lardone, P.J.; Guerrero, J.M.; Carrillo-Vico, A. Melatonin reduces inflammatory response in peripheral T helper lymphocytes from relapsing-remitting multiple sclerosis patients. J. Pineal Res. 2017, 63, e12442. [CrossRef] [PubMed]

235. Ghareghani, M.; Dokoohaki, S.; Ghanbari, A.; Farhadi, N.; Zibara, K.; Khodadoust, S.; Parishani, M.; Ghavamizadeh, M.; Sadeghi, H. Melatonin exacerbates acute experimental autoimmune encephalomyelitis by enhancing the serum levels of lactate: A potential biomarker of multiple sclerosis progression. Clin. Exp. Pharmacol. Physiol. 2017, 44, 52-61. [CrossRef]

236. Reiter, R.J.; Cabrera, J.; Sainz, R.M.; Mayo, J.C.; Manchester, L.C.; Tan, D.X. Melatonin as a pharmacological agent against neuronal loss in experimental models of Huntington's disease, Alzheimer's disease and parkinsonism. Ann. N. Y. Acad. Sci. 1999, 890, 471-485. [CrossRef] 
237. Pappolla, M.A.; Chyan, Y.J.; Poeggeler, B.; Frangione, B.; Wilson, G.; Ghiso, J.; Reiter, R.J. An assessment of the antioxidant and the antiamyloidogenic properties of melatonin: Implications for Alzheimer's disease. J. Neural Transm. 2000, 107, 203-231. [CrossRef]

238. Hardeland, R.; Cardinali, D.P.; Srinivasan, V.; Spence, D.W.; Brown, G.M.; Pandi-Perumal, S.R. Melatonin-A pleiotropic, orchestrating regulator molecule. Prog. Neurobiol. 2011, 93, 350-384. [CrossRef] [PubMed]

239. Watson, N.; Diamandis, T.; Gonzales-Portillo, C.; Reyes, S.; Borlongan, C.V. Melatonin as an Antioxidant for Stroke Neuroprotection. Cell Transplant. 2016, 25, 883-891. [CrossRef] [PubMed]

240. Patino, P.; Parada, E.; Farre-Alins, V.; Molz, S.; Cacabelos, R.; Marco-Contelles, J.; Lopez, M.G.; Tasca, C.I.; Ramos, E.; Romero, A.; et al. Melatonin protects against oxygen and glucose deprivation by decreasing extracellular glutamate and Nox-derived ROS in rat hippocampal slices. Neurotoxicology 2016, 57, 61-68. [CrossRef] [PubMed]

241. Bhattacharya, P.; Pandey, A.K.; Paul, S.; Patnaik, R. Melatonin renders neuroprotection by protein kinase C mediated aquaporin-4 inhibition in animal model of focal cerebral ischemia. Life Sci. 2014, 100, 97-109. [CrossRef] [PubMed]

242. Chern, C.M.; Liao, J.F.; Wang, Y.H.; Shen, Y.C. Melatonin ameliorates neural function by promoting endogenous neurogenesis through the MT2 melatonin receptor in ischemic-stroke mice. Free Radic. Biol. Med. 2012, 52, 1634-1647. [CrossRef]

243. Li, H.; Wang, Y.; Feng, D.; Liu, Y.; Xu, M.; Gao, A.; Tian, F.; Zhang, L.; Cui, Y.; Wang, Z.; et al. Alterations in the time course of expression of the Nox family in the brain in a rat experimental cerebral ischemia and reperfusion model: Effects of melatonin. $J$. Pineal Res. 2014, 57, 110-119. [CrossRef] [PubMed]

244. Daniels, W.M.; van Rensburg, S.J.; van Zyl, J.M.; Taljaard, J.J. Melatonin prevents beta-amyloid-induced lipid peroxidation. J. Pineal Res. 1998, 24, 78-82. [CrossRef] [PubMed]

245. Srinivasan, V.; Pandi-Perumal, S.R.; Maestroni, G.J.; Esquifino, A.I.; Hardeland, R.; Cardinali, D.P. Role of melatonin in neurodegenerative diseases. Neurotox Res. 2005, 7, 293-318. [CrossRef]

246. Zhou, J.; Zhang, S.; Zhao, X.; Wei, T. Melatonin impairs NADPH oxidase assembly and decreases superoxide anion production in microglia exposed to amyloid-beta1-42. J. Pineal Res. 2008, 45, 157-165. [CrossRef] [PubMed]

247. Acuna-Castroviejo, D.; Coto-Montes, A.; Gaia Monti, M.; Ortiz, G.G.; Reiter, R.J. Melatonin is protective against MPTP-induced striatal and hippocampal lesions. Life Sci. 1997, 60, PL23-PL29. [CrossRef]

248. Saravanan, K.S.; Sindhu, K.M.; Mohanakumar, K.P. Melatonin protects against rotenone-induced oxidative stress in a hemiparkinsonian rat model. J. Pineal Res. 2007, 42, 247-253. [CrossRef]

249. Dabbeni-Sala, F.; di Santo, S.; Franceschini, D.; Skaper, S.D.; Giusti, P. Melatonin protects against 6-OHDA-induced neurotoxicity in rats: A role for mitochondrial complex I activity. FASEB J. 2001, 15, 164-170. [CrossRef] [PubMed]

250. Singhal, N.K.; Srivastava, G.; Patel, D.K.; Jain, S.K.; Singh, M.P. Melatonin or silymarin reduces maneb- and paraquat-induced Parkinson's disease phenotype in the mouse. J. Pineal Res. 2011, 50, 97-109. [CrossRef]

251. Valdes-Tovar, M.; Estrada-Reyes, R.; Solis-Chagoyan, H.; Argueta, J.; Dorantes-Barron, A.M.; Quero-Chavez, D.; Cruz-Garduno, R.; Cercos, M.G.; Trueta, C.; Oikawa-Sala, J.; et al. Circadian modulation of neuroplasticity by melatonin: A target in the treatment of depression. Br. J. Pharmacol. 2018, 175, 3200-3208. [CrossRef] [PubMed]

252. Ramirez-Rodriguez, G.; Klempin, F.; Babu, H.; Benitez-King, G.; Kempermann, G. Melatonin modulates cell survival of new neurons in the hippocampus of adult mice. Neuropsychopharmacology 2009, 34, 2180-2191. [CrossRef] [PubMed]

253. Liu, J.; Somera-Molina, K.C.; Hudson, R.L.; Dubocovich, M.L. Melatonin potentiates running wheel-induced neurogenesis in the dentate gyrus of adult C3H/HeN mice hippocampus. J. Pineal Res. 2013, 54, 222-231. [CrossRef]

254. Rennie, K.; de Butte, M.; Pappas, B.A. Melatonin promotes neurogenesis in dentate gyrus in the pinealectomized rat. J. Pineal Res. 2009, 47, 313-317. [CrossRef] [PubMed]

255. Liu, D.; Wei, N.; Man, H.Y.; Lu, Y.; Zhu, L.Q.; Wang, J.Z. The MT2 receptor stimulates axonogenesis and enhances synaptic transmission by activating Akt signaling. Cell Death Differ. 2015, 22, 583-596. [CrossRef]

256. Dominguez-Alonso, A.; Valdes-Tovar, M.; Solis-Chagoyan, H.; Benitez-King, G. Melatonin stimulates dendrite formation and complexity in the hilar zone of the rat hippocampus: Participation of the Ca++/Calmodulin complex. Int. J. Mol. Sci. 2015, 16, 1907-1927. [CrossRef] [PubMed]

257. Stefanova, N.A.; Maksimova, K.Y.; Kiseleva, E.; Rudnitskaya, E.A.; Muraleva, N.A.; Kolosova, N.G. Melatonin attenuates impairments of structural hippocampal neuroplasticity in OXYS rats during active progression of Alzheimer's disease-like pathology. J. Pineal Res. 2015, 59, 163-177. [CrossRef] [PubMed]

258. Zhang, S.; Wang, P.; Ren, L.; Hu, C.; Bi, J. Protective effect of melatonin on soluble Abeta1-42-induced memory impairment, astrogliosis, and synaptic dysfunction via the Musashi1/Notch1/Hes1 signaling pathway in the rat hippocampus. Alzheimers Res. Ther. 2016, 8, 40. [CrossRef] [PubMed]

259. Zhao, Y.; Wang, H.; Chen, W.; Chen, L.; Liu, D.; Wang, X.; Wang, X. Melatonin attenuates white matter damage after focal brain ischemia in rats by regulating the TLR4/NF-kappaB pathway. Brain Res. Bull. 2019, 150, 168-178. [CrossRef]

260. Villapol, S.; Fau, S.; Renolleau, S.; Biran, V.; Charriaut-Marlangue, C.; Baud, O. Melatonin promotes myelination by decreasing white matter inflammation after neonatal stroke. Pediatr. Res. 2011, 69, 51-55. [CrossRef]

261. Tsai, T.H.; Lin, C.J.; Chua, S.; Chung, S.Y.; Yang, C.H.; Tong, M.S.; Hang, C.L. Melatonin attenuated the brain damage and cognitive impairment partially through MT2 melatonin receptor in mice with chronic cerebral hypoperfusion. Oncotarget 2017, 8 , 74320-74330. [CrossRef] [PubMed]

262. Pascual, R.; Bustamante, C. Melatonin promotes distal dendritic ramifications in layer II/III cortical pyramidal cells of rats exposed to toluene vapors. Brain Res. 2010, 1355, 214-220. [CrossRef] [PubMed] 
263. De Butte, M.; Pappas, B.A. Pinealectomy causes hippocampal CA1 and CA3 cell loss: Reversal by melatonin supplementation. Neurobiol. Aging 2007, 28, 306-313. [CrossRef] [PubMed]

264. Liu, J.; Clough, S.J.; Dubocovich, M.L. Role of the MT1 and MT2 melatonin receptors in mediating depressive- and anxiety-like behaviors in C3H/HeN mice. Genes Brain Behav. 2017, 16, 546-553. [CrossRef] [PubMed]

265. Anderson, G. Linking the biological underpinnings of depression: Role of mitochondria interactions with melatonin, inflammation, sirtuins, tryptophan catabolites, DNA repair and oxidative and nitrosative stress, with consequences for classification and cognition. Prog. Neuropsychopharmacol. Biol. Psychiatry 2018, 80, 255-266. [CrossRef] [PubMed]

266. Etain, B.; Milhiet, V.; Bellivier, F.; Leboyer, M. Genetics of circadian rhythms and mood spectrum disorders. Eur. Neuropsychopharmacol. 2011, 21, S676-S682. [CrossRef]

267. Demirkan, A.; Lahti, J.; Direk, N.; Viktorin, A.; Lunetta, K.L.; Terracciano, A.; Nalls, M.A.; Tanaka, T.; Hek, K.; Fornage, M.; et al. Somatic, positive and negative domains of the Center for Epidemiological Studies Depression (CES-D) scale: A meta-analysis of genome-wide association studies. Psychol. Med. 2016, 46, 1613-1623. [CrossRef] [PubMed]

268. Norman, T.R.; Olver, J.S. Agomelatine for depression: Expanding the horizons? Expert Opin. Pharmacother. 2019, $20,647-656$. [CrossRef] [PubMed]

269. Mantovani, M.; Pertile, R.; Calixto, J.B.; Santos, A.R.; Rodrigues, A.L. Melatonin exerts an antidepressant-like effect in the tail suspension test in mice: Evidence for involvement of N-methyl-D-aspartate receptors and the L-arginine-nitric oxide pathway. Neurosci. Lett. 2003, 343, 1-4. [CrossRef]

270. Raghavendra, V.; Kaur, G.; Kulkarni, S.K. Anti-depressant action of melatonin in chronic forced swimming-induced behavioral despair in mice, role of peripheral benzodiazepine receptor modulation. Eur. Neuropsychopharmacol. 2000, 10, 473-481. [CrossRef]

271. Detanico, B.C.; Piato, A.L.; Freitas, J.J.; Lhullier, F.L.; Hidalgo, M.P.; Caumo, W.; Elisabetsky, E. Antidepressant-like effects of melatonin in the mouse chronic mild stress model. Eur. J. Pharmacol. 2009, 607, 121-125. [CrossRef] [PubMed]

272. Micale, V.; Arezzi, A.; Rampello, L.; Drago, F. Melatonin affects the immobility time of rats in the forced swim test: The role of serotonin neurotransmission. Eur. Neuropsychopharmacol. 2006, 16, 538-545. [CrossRef] [PubMed]

273. Weil, Z.M.; Hotchkiss, A.K.; Gatien, M.L.; Pieke-Dahl, S.; Nelson, R.J. Melatonin receptor (MT1) knockout mice display depressionlike behaviors and deficits in sensorimotor gating. Brain Res. Bull. 2006, 68, 425-429. [CrossRef] [PubMed]

274. Madsen, M.T.; Isbrand, A.; Andersen, U.O.; Andersen, L.J.; Taskiran, M.; Simonsen, E.; Gogenur, I. The effect of MElatonin on Depressive symptoms, Anxiety, CIrcadian and Sleep disturbances in patients after acute coronary syndrome (MEDACIS): Study protocol for a randomized controlled trial. Trials 2017, 18, 81. [CrossRef] [PubMed]

275. Garzon, C.; Guerrero, J.M.; Aramburu, O.; Guzman, T. Effect of melatonin administration on sleep, behavioral disorders and hypnotic drug discontinuation in the elderly: A randomized, double-blind, placebo-controlled study. Aging Clin. Exp. Res. 2009, 21, 38-42. [CrossRef] [PubMed]

276. Gray, J.P.; Muller, V.I.; Eickhoff, S.B.; Fox, P.T. Multimodal Abnormalities of Brain Structure and Function in Major Depressive Disorder: A Meta-Analysis of Neuroimaging Studies. Am. J. Psychiatry 2020, 177, 422-434. [CrossRef] [PubMed]

277. Slavich, G.M.; Irwin, M.R. From stress to inflammation and major depressive disorder: A social signal transduction theory of depression. Psychol. Bull. 2014, 140, 774-815. [CrossRef]

278. Chesnokova, V.; Pechnick, R.N.; Wawrowsky, K. Chronic peripheral inflammation, hippocampal neurogenesis, and behavior. Brain Behav. Immun. 2016, 58, 1-8. [CrossRef] [PubMed]

279. Dominguez-Alonso, A.; Ramirez-Rodriguez, G.; Benitez-King, G. Melatonin increases dendritogenesis in the hilus of hippocampal organotypic cultures. J. Pineal Res. 2012, 52, 427-436. [CrossRef] [PubMed]

280. Soumier, A.; Banasr, M.; Lortet, S.; Masmejean, F.; Bernard, N.; Kerkerian-Le-Goff, L.; Gabriel, C.; Millan, M.J.; Mocaer, E.; Daszuta, A. Mechanisms contributing to the phase-dependent regulation of neurogenesis by the novel antidepressant, agomelatine, in the adult rat hippocampus. Neuropsychopharmacology 2009, 34, 2390-2403. [CrossRef] [PubMed]

281. Paizanis, E.; Renoir, T.; Lelievre, V.; Saurini, F.; Melfort, M.; Gabriel, C.; Barden, N.; Mocaer, E.; Hamon, M.; Lanfumey, L. Behavioural and neuroplastic effects of the new-generation antidepressant agomelatine compared to fluoxetine in glucocorticoid receptor-impaired mice. Int. J. Neuropsychopharmacol. 2010, 13, 759-774. [CrossRef] [PubMed]

282. Banasr, M.; Soumier, A.; Hery, M.; Mocaer, E.; Daszuta, A. Agomelatine, a new antidepressant, induces regional changes in hippocampal neurogenesis. Biol. Psychiatry 2006, 59, 1087-1096. [CrossRef]

283. Gumuslu, E.; Mutlu, O.; Sunnetci, D.; Ulak, G.; Celikyurt, I.K.; Cine, N.; Akar, F.; Savli, H.; Erden, F. The Antidepressant Agomelatine Improves Memory Deterioration and Upregulates CREB and BDNF Gene Expression Levels in Unpredictable Chronic Mild Stress (UCMS)-Exposed Mice. Drug Target Insights 2014, 8, 11-21. [CrossRef] [PubMed]

284. Kondratova, A.A.; Kondratov, R.V. The circadian clock and pathology of the ageing brain. Nat. Rev. Neurosci. 2012, 13, 325-335. [CrossRef] [PubMed]

285. Hastings, M.H.; Goedert, M. Circadian clocks and neurodegenerative diseases: Time to aggregate? Curr. Opin. Neurobiol. 2013, 23, 880-887. [CrossRef] [PubMed]

286. Videnovic, A.; Lazar, A.S.; Barker, R.A.; Overeem, S. 'The clocks that time us'—Circadian rhythms in neurodegenerative disorders. Nat. Rev. Neurol. 2014, 10, 683-693. [CrossRef] [PubMed]

287. Abbott, S.M.; Videnovic, A. Chronic sleep disturbance and neural injury: Links to neurodegenerative disease. Nat. Sci. Sleep 2016, 8, 55-61. [PubMed] 
288. Mattis, J.; Sehgal, A. Circadian Rhythms, Sleep, and Disorders of Aging. Trends Endocrinol. Metab. 2016, 27, 192-203. [CrossRef] [PubMed]

289. Medeiros, C.A.; Carvalhedo de Bruin, P.F.; Lopes, L.A.; Magalhaes, M.C.; de Lourdes Seabra, M.; de Bruin, V.M. Effect of exogenous melatonin on sleep and motor dysfunction in Parkinson's disease. A randomized, double blind, placebo-controlled study. J. Neurol. 2007, 254, 459-464. [CrossRef] [PubMed]

290. Asayama, K.; Yamadera, H.; Ito, T.; Suzuki, H.; Kudo, Y.; Endo, S. Double blind study of melatonin effects on the sleep-wake rhythm, cognitive and non-cognitive functions in Alzheimer type dementia. J. Nippon Med. Sch. 2003, 70, 334-341. [CrossRef] [PubMed]

291. Riemersma-van der Lek, R.F.; Swaab, D.F.; Twisk, J.; Hol, E.M.; Hoogendijk, W.J.; van Someren, E.J. Effect of bright light and melatonin on cognitive and noncognitive function in elderly residents of group care facilities: A randomized controlled trial. JAMA 2008, 299, 2642-2655. [CrossRef]

292. Gehrman, P.R.; Connor, D.J.; Martin, J.L.; Shochat, T.; Corey-Bloom, J.; Ancoli-Israel, S. Melatonin fails to improve sleep or agitation in double-blind randomized placebo-controlled trial of institutionalized patients with Alzheimer disease. Am. J. Geriatr. Psychiatry 2009, 17, 166-169. [CrossRef]

293. De Jonghe, A.; Korevaar, J.C.; van Munster, B.C.; de Rooij, S.E. Effectiveness of melatonin treatment on circadian rhythm disturbances in dementia. Are there implications for delirium? A systematic review. Int. J. Geriatr. Psychiatry 2010, 25, 1201-1208. [CrossRef] [PubMed]

294. Hood, S.; Amir, S. Neurodegeneration and the Circadian Clock. Front. Aging Neurosci. 2017, 9, 170. [CrossRef] [PubMed]

295. Muller, N.; Schwarz, M.J.; Dehning, S.; Douhe, A.; Cerovecki, A.; Goldstein-Muller, B.; Spellmann, I.; Hetzel, G.; Maino, K.; Kleindienst, N.; et al. The cyclooxygenase-2 inhibitor celecoxib has therapeutic effects in major depression: Results of a double-blind, randomized, placebo controlled, add-on pilot study to reboxetine. Mol. Psychiatry 2006, 11, 680-684. [CrossRef] [PubMed]

296. Abbasi, S.H.; Hosseini, F.; Modabbernia, A.; Ashrafi, M.; Akhondzadeh, S. Effect of celecoxib add-on treatment on symptoms and serum IL-6 concentrations in patients with major depressive disorder: Randomized double-blind placebo-controlled study. $J$. Affect. Disord. 2012, 141, 308-314. [CrossRef]

297. Akhondzadeh, S.; Jafari, S.; Raisi, F.; Nasehi, A.A.; Ghoreishi, A.; Salehi, B.; Mohebbi-Rasa, S.; Raznahan, M.; Kamalipour, A. Clinical trial of adjunctive celecoxib treatment in patients with major depression: A double blind and placebo controlled trial. Anxiety 2009, 26, 607-611. [CrossRef] [PubMed]

298. Menter, A.; Augustin, M.; Signorovitch, J.; Yu, A.P.; Wu, E.Q.; Gupta, S.R.; Bao, Y.; Mulani, P. The effect of adalimumab on reducing depression symptoms in patients with moderate to severe psoriasis: A randomized clinical trial. J. Am. Acad. Dermatol. 2010, 62, 812-818. [CrossRef] [PubMed]

299. Ertenli, I.; Ozer, S.; Kiraz, S.; Apras, S.B.; Akdogan, A.; Karadag, O.; Calguneri, M.; Kalyoncu, U. Infliximab, a TNF-alpha antagonist treatment in patients with ankylosing spondylitis: The impact on depression, anxiety and quality of life level. Rheumatol. Int. 2012, 32, 323-330. [CrossRef] [PubMed]

300. Mendlewicz, J.; Kriwin, P.; Oswald, P.; Souery, D.; Alboni, S.; Brunello, N. Shortened onset of action of antidepressants in major depression using acetylsalicylic acid augmentation: A pilot open-label study. Int. Clin. Psychopharmacol. 2006, 21, $227-231$. [CrossRef]

301. Miyaoka, T.; Wake, R.; Furuya, M.; Liaury, K.; Ieda, M.; Kawakami, K.; Tsuchie, K.; Taki, M.; Ishihara, K.; Araki, T.; et al. Minocycline as adjunctive therapy for patients with unipolar psychotic depression: An open-label study. Prog. Neuropsychopharmacol. Biol. Psychiatry 2012, 37, 222-226. [CrossRef] [PubMed] 